E International

Time to Sweat the Assets? The analysis of two airport cases of restricted capacity in different continents

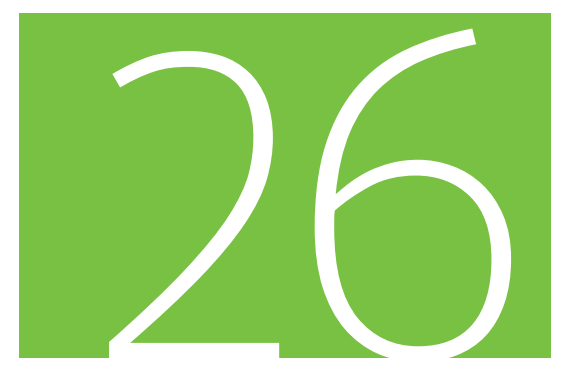

Discussion Paper 2017 • 26

Miguel Mujica Mota and Geert Boosten

Aviation Academy of Amsterdam University of Applied Sciences, The Netherlands

\title{
Catya Zuniga
}

Aeronautic University of Querétaro, Querétaro, México 


\title{
EInternational Transport Forum
}

\section{Time to Sweat the Assets?}

\section{The analysis of two airport cases of restricted capacity in different continents}

\author{
Discussion Paper No. 2017-26
}

Prepared for the Roundtable on

Capacity Building through Efficient Use of Existing Airport Infrastructure

9-10 March 2017, Querétaro

\section{Miguel Mujica Mota \\ Geert Boosten}

Aviation Academy of Amsterdam University of Applied Sciences, The Netherlands

\section{Catya Zuniga}

Aeronautic University of Querétaro, Querétaro, México

September 2017 


\title{
The International Transport Forum
}

The International Transport Forum is an intergovernmental organisation with 59 member countries. It acts as a think tank for transport policy and organises the Annual Summit of transport ministers. ITF is the only global body that covers all transport modes. The ITF is politically autonomous and administratively integrated with the OECD.

The ITF works for transport policies that improve peoples' lives. Our mission is to foster a deeper understanding of the role of transport in economic growth, environmental sustainability and social inclusion and to raise the public profile of transport policy.

The ITF organises global dialogue for better transport. We act as a platform for discussion and pre-negotiation of policy issues across all transport modes. We analyse trends, share knowledge and promote exchange among transport decision-makers and civil society. The ITF's Annual Summit is the world's largest gathering of transport ministers and the leading global platform for dialogue on transport policy.

The Members of the Forum are: Albania, Armenia, Argentina, Australia, Austria, Azerbaijan, Belarus, Belgium, Bosnia and Herzegovina, Bulgaria, Canada, Chile, China (People's Republic of), Croatia, Czech Republic, Denmark, Estonia, Finland, France, Former Yugoslav Republic of Macedonia, Georgia, Germany, Greece, Hungary, Iceland, India, Ireland, Israel, Italy, Japan, Kazakhstan, Korea, Latvia, Liechtenstein, Lithuania, Luxembourg, Malta, Mexico, Republic of Moldova, Montenegro, Morocco, the Netherlands, New Zealand, Norway, Poland, Portugal, Romania, Russian Federation, Serbia, Slovak Republic, Slovenia, Spain, Sweden, Switzerland, Turkey, Ukraine, the United Arab Emirates, the United Kingdom and the United States.

\author{
International Transport Forum \\ 2 rue André Pascal \\ F-75775 Paris Cedex 16 \\ contact@itf-oecd.org \\ WWW.itf-oecd.org
}

\section{ITF Discussion Papers}

ITF Discussion Papers make economic research, commissioned or carried out in-house at ITF, available to researchers and practitioners. They describe preliminary results or research in progress by the author(s) and are published to stimulate discussion on a broad range of issues on which the ITF works. Any findings, interpretations and conclusions expressed herein are those of the authors and do not necessarily reflect the views of the International Transport Forum or the OECD. Neither the OECD, ITF nor the authors guarantee the accuracy of any data or other information contained in this publication and accept no responsibility whatsoever for any consequence of their use. This document and any map included herein are without prejudice to the status of or sovereignty over any territory, to the delimitation of international frontiers and boundaries and to the name of any territory, city or area. Comments on Discussion Papers are welcome. 


\begin{abstract}
Air traffic numbers have been steadily increasing and are projected to so in the future. Most traffic growth pertains to a small fraction of the total available airport capacity worldwide; particularly the main airport hubs present these trends. As a consequence, they are becoming increasingly congested, which results in the increase of delays and reduction of reliability. For these reasons it is important to look for ways in which the existing assets can take up more traffic. These solutions should go beyond long-term considerations to build more infrastructures. In the current paper we discuss of different ways of increasing capacity. First we define capacity and then we discuss techniques for identifying bottlenecks and room for improvement. We exemplify them by providing two examples of airports in different continents, Schiphol Airport and Mexico City Airport.
\end{abstract}




\section{Table of contents}

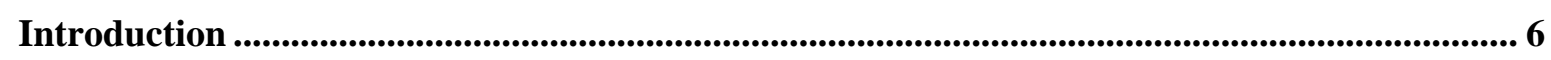

Defining and measuring airport capacity ............................................................................................. 6

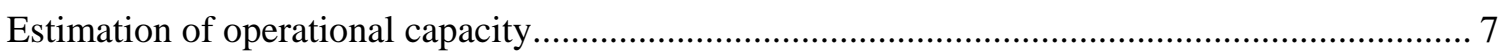

Amsterdam Schiphol Airport ................................................................................................................... 9

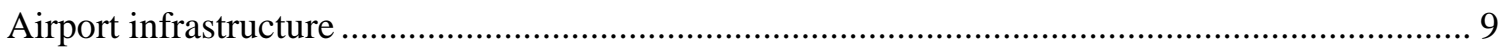

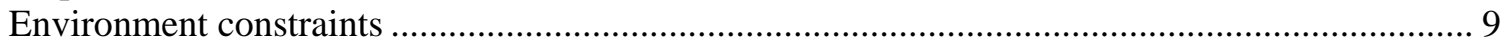

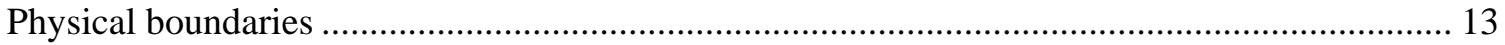

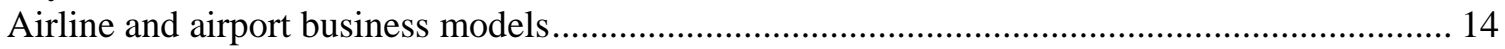

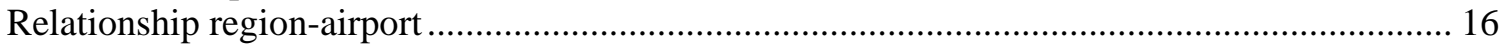

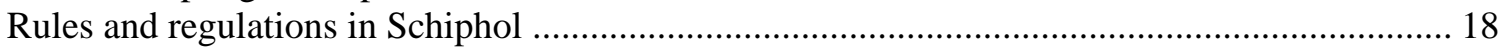

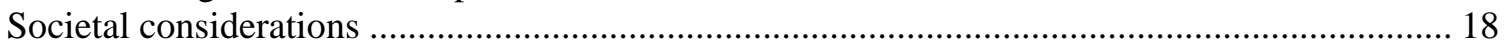

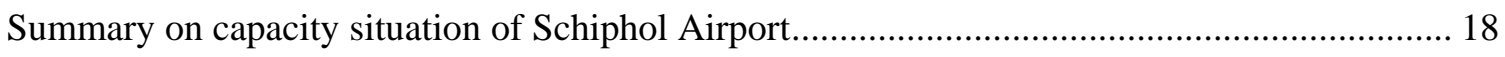

Mexico City Airport ................................................................................................................................. 20

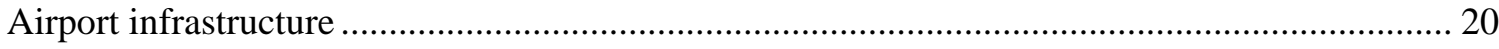

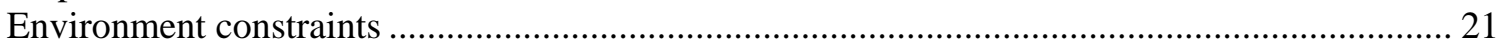

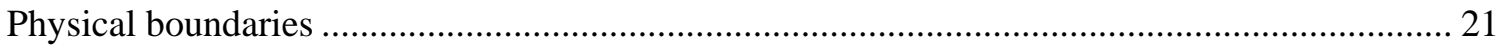

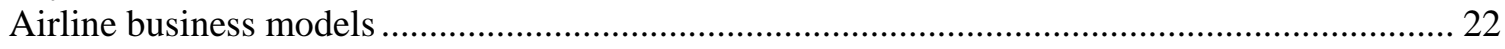

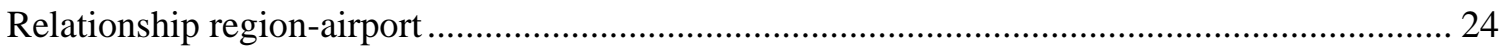

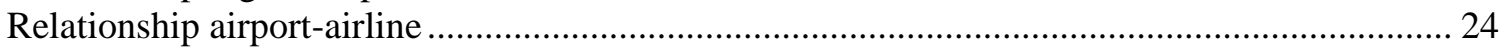

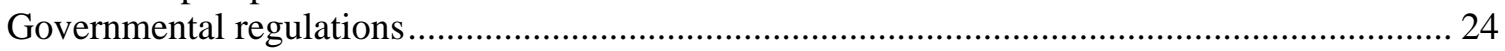

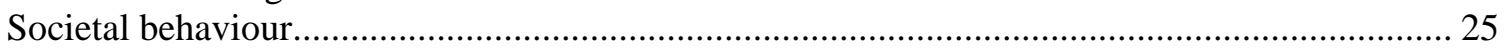

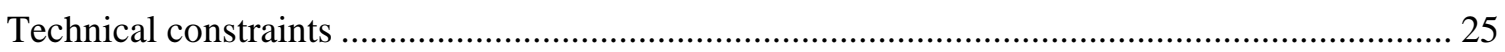

Identifying potential for growth by a simulation-based analysis .............................................. 25

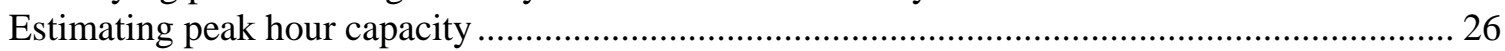

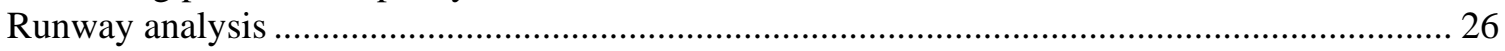

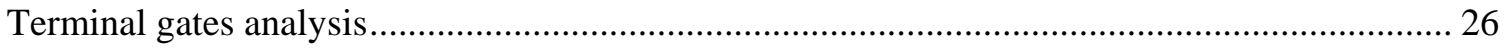

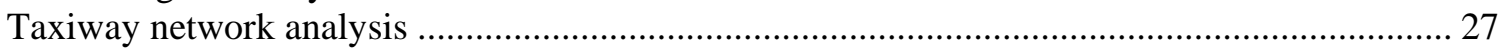

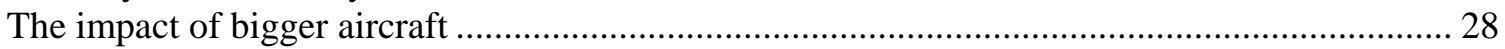

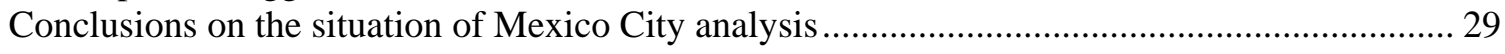

Comparison of Schiphol and International Airport of Mexico City ........................................... 29

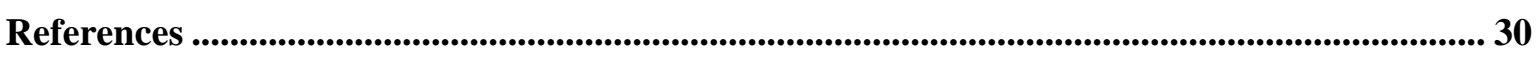

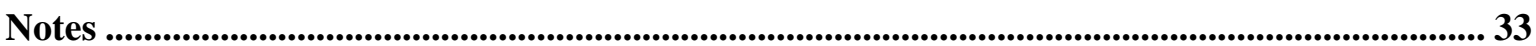

\section{Figures}

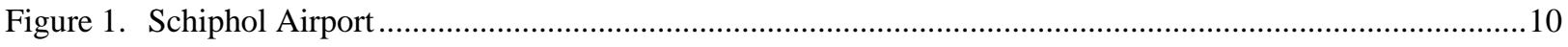

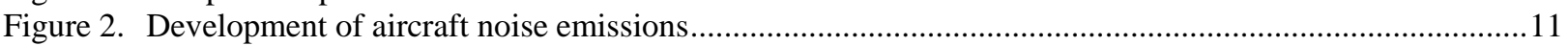

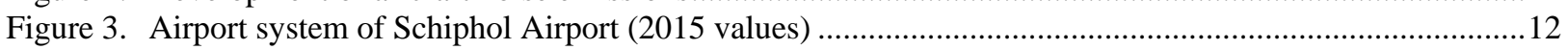

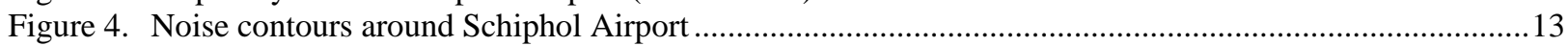




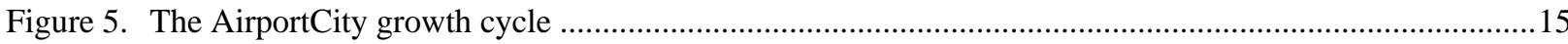

Figure 6. The triple helix as growth model for Schiphol Airport ......................................................................17

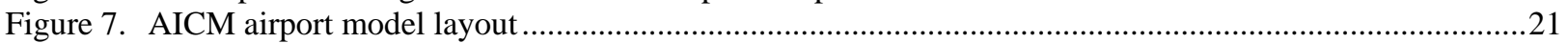

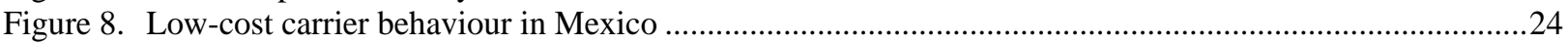

Figure 9. Effect of the introduction of the A380 in the RWY utilisation.............................................................28

\section{Tables}

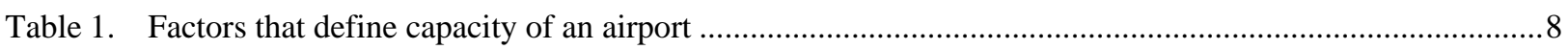

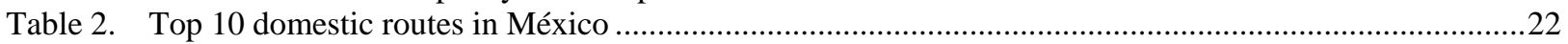

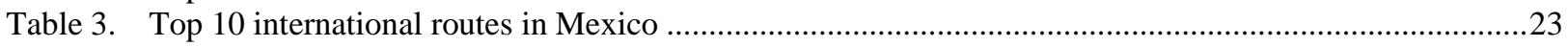

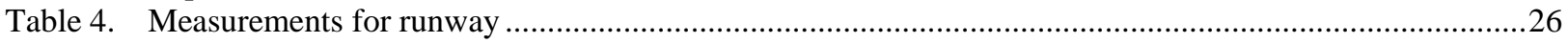

Table 5. Measurements of gate buildings usage for the 30 simulations .......................................................27

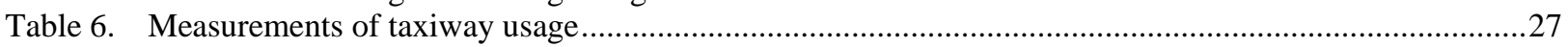




\section{Introduction}

During the past decade, the world economy grew at an average annual rate of $3.6 \%$, measured in terms of Gross Domestic Product (GDP). In the same period, the aviation sector worldwide has been steadily increasing and it has also been forecasted to do so in the future. The total scheduled airline traffic grew at an average annual rate of 5\%, and it has been forecasted a $4.2 \%$ and $6 \%$ steady growth in the next twenty years for advanced and emerging markets, respectively. The airline industry has achieved $7 \%$ compound annual revenue growth, which is more than double that of global economic growth. Specially, in 2014, airlines double industry net profit by USD 20 billion over 2013. In passenger terms, the growth levels imply an additional 150-160 million passengers globally over the 2013 levels (Airbus, 2015; Boeing, 2015).

Most traffic is concentrated at the biggest global airports. Over $80 \%$ of the commercial air traffic is concentrated on the top 100 airports worldwide, most of which face severe capacity constraints now or will face capacity constraints in the near future. The main issue with the steady growth is that airports are becoming increasingly congested, which in turn is a problem because capacity constraints have adverse impacts on welfare. Passengers and businesses are affected by flight delays, cancellations, and missed connections. In general terms, congestion causes delays and reduces reliability. Therefore, in a capacity constrained airport, it is important to look for ways in which the existing assets can take up more traffic. These ways should go beyond long-term considerations to build more infrastructure.

The present paper looks at different factors that affect capacity. It starts by addressing the definition of capacity by several authors, and it presents the multifactorial nature of the definition of capacity. To illustrate this nature, the definition is followed by the analysis of Schiphol Airport capacity constraints and Mexico City airport as a preamble to highlight the benefits of simulation-based analysis of Mexico City to shed light on their capacity constraints and what theoretical potential there is to increase its capacity.

\section{Defining and measuring airport capacity}

Capacity is the main term that comes in mind when congestion problems arise. People can perceive congestion symptoms in different areas of the airport system, in the length of queues inside the terminal building, waiting times for security, amount of people inside the terminal buildings. In addition, queuing in the airside indicates congestion and the ultimate indicator of congestion levels is the daily delay suffered by airlines. Congestion affects all the different stakeholders in different ways. It degrades the Ground Handlers level of services ${ }^{1}$ agreed with the different airlines. The airport operator in turn pays attention to the perception of quality by the passengers and airlines. The airlines pay a lot of attention to these levels for setting new routes or even a hub in the different airports. For the region (businesses, 
passengers, cargo shippers) capacity constraints may result in less connectivity ${ }^{2}$ to other parts of the world. For these reasons, and from discussions with different stakeholders, we perceived that capacity is a term that has different meanings and many factors affect it depending from which angle it considered.

Capacity has been analysed and defined by different authors, however no objective definition can be found because of the multidimensional nature of the concept as the following review illustrates. Reichmuth, Berster and Gelhause (2011) mention that airport capacity is related to a facilitie's capability to handle people, freight and vehicles. Other authors define capacity by the number of movements per hour (Barhart et al., 2012) while Upham et al. (2003), and Graham and Guyer (1999) define capacity as a function of operational and environmental constraints. Recently, academic research on airport operations tends to focus on the relationship between flight schedules, airport capacity and how to mitigate delays (Jacquillat and Odoni, 2015). Other important considerations are land use at and around the airport (Janic, 2016) and the role and contribution of stakeholders for defining the environmental capacity and demand for air traffic (Upham et al., 2004). According to Janic (2008), capacity and development of airports can also be seen as the interaction between four main factors: 1) operational, sizing and design of airside and landside infrastructure, 2) economics, 3) environmental restrictions and regulations and 4) social perception towards airport infrastructures. Some others, like D'Alfonso and Nastasi (2014), study capacity through investigating the relationship between airports and airlines, and their respective business models. The FAA (2015) provides a list of factors that affect capacity constraints: noise, emission reduction, airport slots, separation intervals for landing and departures, meteorological conditions, aerodrome design, runway configuration, arrival/departure ratio, air traffic flow type, aircraft characteristics, and demand-related issues (like fleet mix, runway occupancy time and average ground speed on final approach). We can conclude that airport capacity is not a static factor that defines the amount of aircraft or passengers/cargo handled but that dynamic factors like flight schedules, aircraft types and weather conditions also play an important role in defining airport capacity.

\section{Estimation of operational capacity}

The various airport capacity indicators demonstrate that an overall definition of airport capacity is missing. For this paper, airport capacity is proposed as a multifunction of airline and airport business model, airport infrastructure, regulations, and capacity caps imposed by the government for environmental or society-related reasons. To define airport capacity as a multifactor function leaves open the exact relationships between the factors but stresses that all factors are relevant to assess airport capacity. Therefore the definition of capacity should take into account some factors as the following formula illustrates:

\section{Airport capacity $=f($ Factor 1, Factor 2 , Factor $3 .$. Factor $n)$}

Table 1 is used for shedding more light on the idea of the multidimensionality in the definition of capacity. The table presents the different factors that affect capacity, how they are measured and also potential actions that might be taken for relaxing the restrictions.

The definition of capacity which the authors propose is "dynamic" in the sense that it should take into account that constraining factors can differ per airport, per season, and even per time of the day. A dynamic capacity definition acknowledges that both, operational and strategic phases may result in a different constraining factor and thus capacity limitations. Understanding airport capacity and what drives the capacity usage at airports will provide an insight in the set of instruments available to optimise the use of capacity. In other words, every existing airport will have a different (unique) set of constraining factors and possible solutions to increase the capacity. The following two examples stress the proposed definition, highlight the importance of these factors, and illustrate how different actions can be taken for relaxing restrictions and unleashing capacity. 


\section{Table 1. Factors that define capacity of an airport}

\begin{tabular}{|c|c|c|}
\hline $\begin{array}{l}\text { Limiting } \\
\text { factor }\end{array}$ & Description & Capacity-increasing strategies \\
\hline $\begin{array}{l}\text { Technical } \\
\text { constraints }\end{array}$ & $\begin{array}{l}\text { This parameter has been measured by the maximum } \\
\text { ATMs per hour in a runway in a combined arrival and } \\
\text { departure fashion. Regarding terminal and landside, they } \\
\text { are measured by the maximum amount of passengers per } \\
\text { hour; the standard measure is the peak hour concept. }\end{array}$ & $\begin{array}{l}\text { Paradigms like SESAR and NextGen aim to } \\
\text { remove some technical boundaries by more } \\
\text { efficient trajectories. In addition, techniques like } \\
\text { simulation and optimisation allow getting to the } \\
\text { limits of operational capacity of infrastructures } \\
\text { and systems. Nevertheless there is still the } \\
\text { practice to expand facilities whenever possible } \\
\text { however it is a long-term solution that might take } \\
\text { many years. }\end{array}$ \\
\hline $\begin{array}{l}\text { Environmen } \\
\text { tal } \\
\text { constraints }\end{array}$ & $\begin{array}{l}\text { This parameter refers to imposed limitations due to noise } \\
\text { and emissions that directly affect the wellbeing of the } \\
\text { communities surrounding the airport. These constraints } \\
\text { can put limits on the allowed number of operations } \\
\text { measured in ATMs/season. }\end{array}$ & $\begin{array}{l}\text { For this factor the change in technology and/or } \\
\text { operational procedures can provide more } \\
\text { capacity in the systems. }\end{array}$ \\
\hline $\begin{array}{l}\text { Physical } \\
\text { boundaries }\end{array}$ & $\begin{array}{l}\text { The geographical and type of boundaries of the airport } \\
\text { limit the operation since the noise emission is an } \\
\text { undesirable side effect of the airport operation. In } \\
\text { addition, the influence of inhabitants surrounding the } \\
\text { airport might hinder the operation of the airport in the } \\
\text { vicinity by putting a cap on the allowed ATM } \\
\text { movements. }\end{array}$ & $\begin{array}{l}\text { This factor can be influenced by negotiations } \\
\text { with the communities or by the acquisition of } \\
\text { land in the vicinity of the airport. Land-use } \\
\text { planning is crucial to preserve area for airport } \\
\text { expansion, }\end{array}$ \\
\hline $\begin{array}{l}\text { Airline } \\
\text { business } \\
\text { models }\end{array}$ & $\begin{array}{l}\text { The airline business model affects the capacity more and } \\
\text { more. Some carriers operate under the hub-and-spoke } \\
\text { model while other under a point-point one. These models } \\
\text { directly affect the peak hour operational capacity, } \\
\text { particularly in big international hubs stretching capacity } \\
\text { to its very limits. Airlines often compete with high } \\
\text { frequencies between destinations, thus increasing the } \\
\text { number of movements. In addition, connectivity also has } \\
\text { downsides for this model: the delays in one airport might } \\
\text { be exported and sometimes amplified in another due to } \\
\text { the connectivity, influencing the real capacity. }\end{array}$ & $\begin{array}{l}\text { One of the ways to influence this factor has been } \\
\text { by setting economic incentives or pricing } \\
\text { models. Furthermore, by expanding information } \\
\text { systems from one airport to multiple airports } \\
\text { (gate-to-gate concept) and the use of larger } \\
\text { aircraft to reduce frequencies. }\end{array}$ \\
\hline $\begin{array}{l}\text { Airport } \\
\text { business } \\
\text { models }\end{array}$ & $\begin{array}{l}\text { Some airports invest in real state or inside facilities that } \\
\text { reduce capacity. Some airports decide to make deals to } \\
\text { use their available space for alternative business that } \\
\text { provide revenue instead of using it to expand capacity, } \\
\text { this is a particular case of terminal buildings on the } \\
\text { landside and real estate close to the airside. }\end{array}$ & $\begin{array}{l}\text { The airport needs to clearly define its business } \\
\text { model. This decision might affect expansion } \\
\text { investments. Government regulations can ensure } \\
\text { that airports invest in aeronautical infrastructure } \\
\text { on time. }\end{array}$ \\
\hline $\begin{array}{l}\text { Relationship } \\
\text { airport- } \\
\text { airline }\end{array}$ & $\begin{array}{l}\text { The relationship between these two entities might create } \\
\text { more or less competition which is turn increase or reduce } \\
\text { capacity. These relationships might benefit particular } \\
\text { airlines letting less space for competition in slots where } \\
\text { capacity can be used. }\end{array}$ & $\begin{array}{l}\text { Some authors propose to reduce the relationship } \\
\text { in order to prevent monopolistic behaviour of } \\
\text { airlines. }\end{array}$ \\
\hline $\begin{array}{l}\text { Relationship } \\
\text { region- } \\
\text { airport }\end{array}$ & $\begin{array}{l}\text { Beyond the physical limits there are other stakeholders } \\
\text { whose interests should be considered so that they do not } \\
\text { block or establish capacity limitations. This is the } \\
\text { particular case of communities in the vicinity of the } \\
\text { airport. }\end{array}$ & $\begin{array}{l}\text { In order to relax capacity boundaries, } \\
\text { negotiations should take place between airport } \\
\text { and stake holders. Furthermore more complex } \\
\text { relationships between airports and the region can } \\
\text { arise in response to the limitations of capacity } \\
\text { such as the multi-airport system concept. }\end{array}$ \\
\hline $\begin{array}{l}\text { Government } \\
\text { al } \\
\text { regulations }\end{array}$ & $\begin{array}{l}\text { The government, either pushed by society or by other } \\
\text { entities, can limit the capacity growth by using curfews } \\
\text { or artificial caps which might change during seasons and } \\
\text { even during the day. }\end{array}$ & $\begin{array}{l}\text { For these regulations only the change in } \\
\text { technology might allow the increase in capacity. }\end{array}$ \\
\hline
\end{tabular}


Table 1. Factors that define capacity of an airport (cont.)

\begin{tabular}{|c|c|c|}
\hline $\begin{array}{l}\text { Limiting } \\
\text { factor }\end{array}$ & Description & Capacity-increasing strategies \\
\hline $\begin{array}{l}\text { Societal } \\
\text { behaviour }\end{array}$ & $\begin{array}{l}\text { Disruptive technology can also affect the capacity in } \\
\text { facilities, in which the impact might vary depending on } \\
\text { the technical development of societies. That is the case of } \\
\text { mobile phones: they reduce the uncertainty for } \\
\text { passengers, which is translated into less demand for } \\
\text { space inside terminal buildings. In the future this might } \\
\text { imply less processing time from arrival to departure, thus } \\
\text { leading in an increase of capacity at different levels. The } \\
\text { behaviour of people together with the evolution of more } \\
\text { efficient aircraft might cause passengers to choose for } \\
\text { more point-point flights avoiding the use of big hubs. }\end{array}$ & $\begin{array}{l}\text { Studies should be performed for evaluating to } \\
\text { what extent capacity in different areas is } \\
\text { impacted. These may result in new operating } \\
\text { models for airports. }\end{array}$ \\
\hline
\end{tabular}

\section{Amsterdam Schiphol Airport}

\section{Airport infrastructure}

Schiphol is a large airport with five main runways and one terminal split into three halls. In terms of operations it has a good performance in comparison to other airports in Europe as suggested the overall punctuality of $81.15 \%$, measured as 15-minute tolerance in 2015 (OAG, 2016). The airport has 110 air traffic movements (ATM) peak hour capacity ${ }^{3}$ with an average of 76 ATM at off-peak time. Its operations are limited during the evening and at night (Netherlands, 2016). In 2017 the maximum number of movements is restricted to 500000 ATMs which is a reduction of 10000 ATMs compared to 2015.

Schiphol is part of the European network and has declared a high operational capacity; the traffic growth will make it increasingly difficult to keep its performance in practice as declared due to the constraining factors that complicate the operations and limit the airport capacity development.

\section{Environment constraints}

At Schiphol there have been capacity limitations due to the amount of generated noise by the aircraft since the 1960s. As from 1967 (Deventer, 2010) Schiphol can be perceived as noise-constrained, but the extent to which noise limitations constrained the airport has changed over time. The constraints forced the definition of a noise contour around the airport, limiting the amount of particularly noisy aircraft. The maximum noise perceived by the houses and by 2050 sensors within the contour also affects the preferred runway usage. In the year 2003 the runway known as Polderbaan (see Figure 1) was constructed in response to community complaints in addition to the imposed annual limit of ATMs in the airport. Furthermore, the noise limits also influenced the establishment of an informal airport system with other Dutch airports to guarantee the continuous growth of traffic in case Schiphol meets the maximum number of ATM.The agreement among the stakeholders includes that the $50 \%$ of potential capacity gains due to the use of new (quieter) technology within the current noise limits will not be used and returned to the communities thus reducing the noise while at the same time allowing the increase of more ATMs per year. Figure 2 illustrates that new aircraft produce less noise. So if the fleet composition 
at Schiphol Airport will consist of more latest-technology aircraft the total annual noise produced by these aircraft will be less than today. The noise reduction will be split in half; only $50 \%$ will be used to grow the maximum of ATMs at the airport. The other $50 \%$ will in fact reduce the annual amount of noise produced.

\section{Figure 1. Schiphol Airport}



Source: Google maps. 
Figure 2. Development of aircraft noise emissions

\section{Development of aircraft noise emissions}

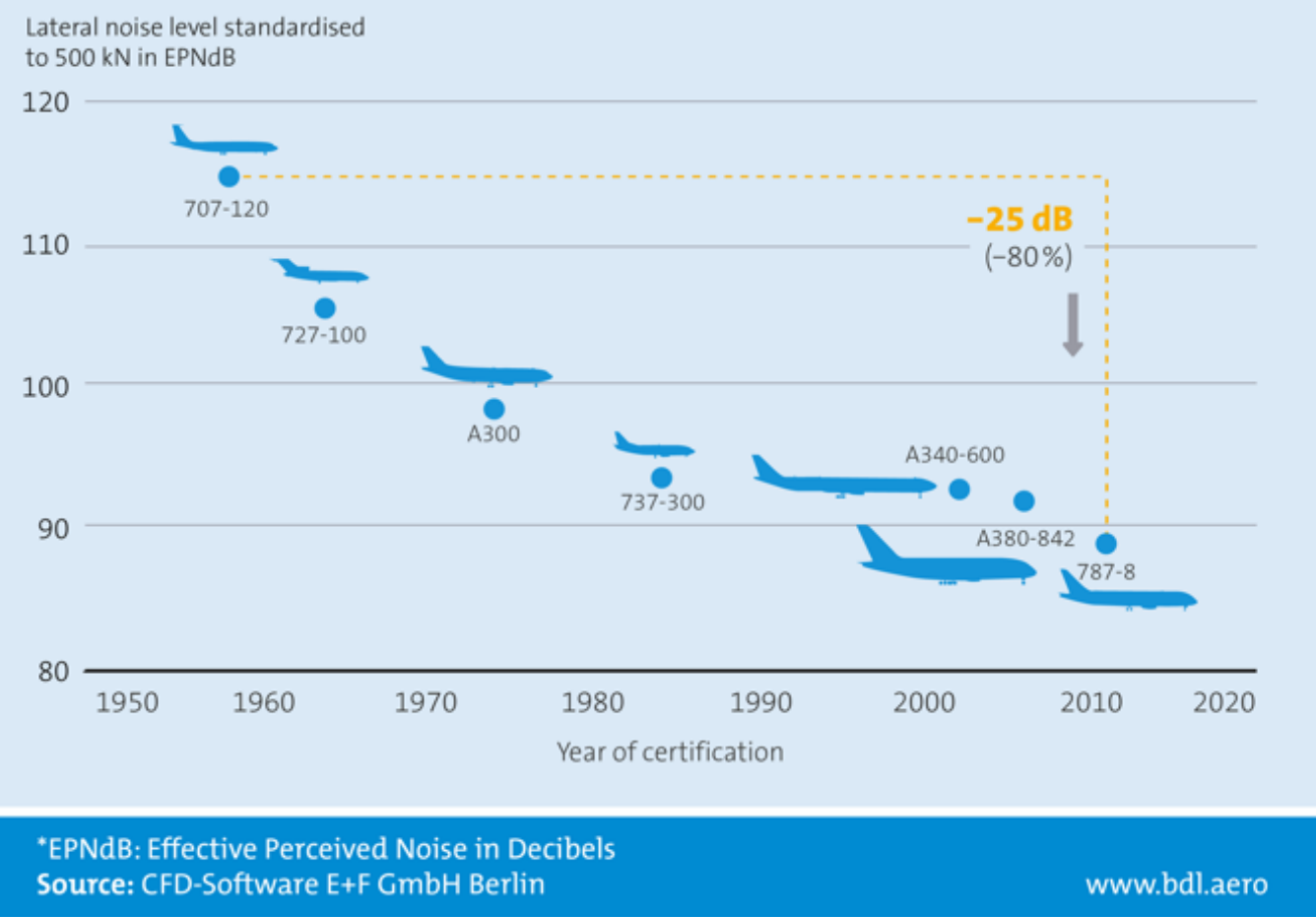

Source: Bundesverband der Deutschen Luftverkehrswirtschaft (2015).

Hence, today the noise around the airport is contained by (Deventer, 2010):

- limitation of 500000 ATMs per annum

- $\quad$ rules for air space usage (minimum flight levels, strict standard arrival and departure routes)

- rules for runway system availability and runway usage at various moments of the day (day, evening, night)

- rules about noise-preferential runway usage

- minimising the number of noise hindered houses, serious hindered persons and persons with disturbed sleep patterns.

If Schiphol exceeds its ATM limit, part of the traffic has to be moved to other airports in the Netherlands. The advisory board for Schiphol airport suggested that priority must be put to those airlines that play an important role in the development of the hub function of the airport due to its small catchment area. For this reason, LCCs and charter traffic would be the ones that more easily can divert their operations to other airports in the vicinity if Schiphol, namely Rotterdam, Eindhoven and in the future Lelystad. Figure 3 provides an overview of the airport system designed to handle the overflow. 


\section{Box 1. Slot limitations at Schiphol}

In 2017 Schiphol Airport expects to hit the 500000 ATM ceiling. The limited number of slots raises questions on how to allocate the scarce capacity. Should this be given to the hub carrier or divided amongst all parties demanding capacity at Schiphol Airport? By February 2017 still 12000 slots are not yet allocated; these are requested from parties that have not received a slot at all and parties that want to improve their slot time. A party like holiday charter TUI (the third biggest operator at Schiphol) claims to have received less slots than it should have based on historic rights. How capacity is defined at Schiphol is not clear; last year airlines and airport had a fierce discussion on this topic. (Cohen, 2017a)

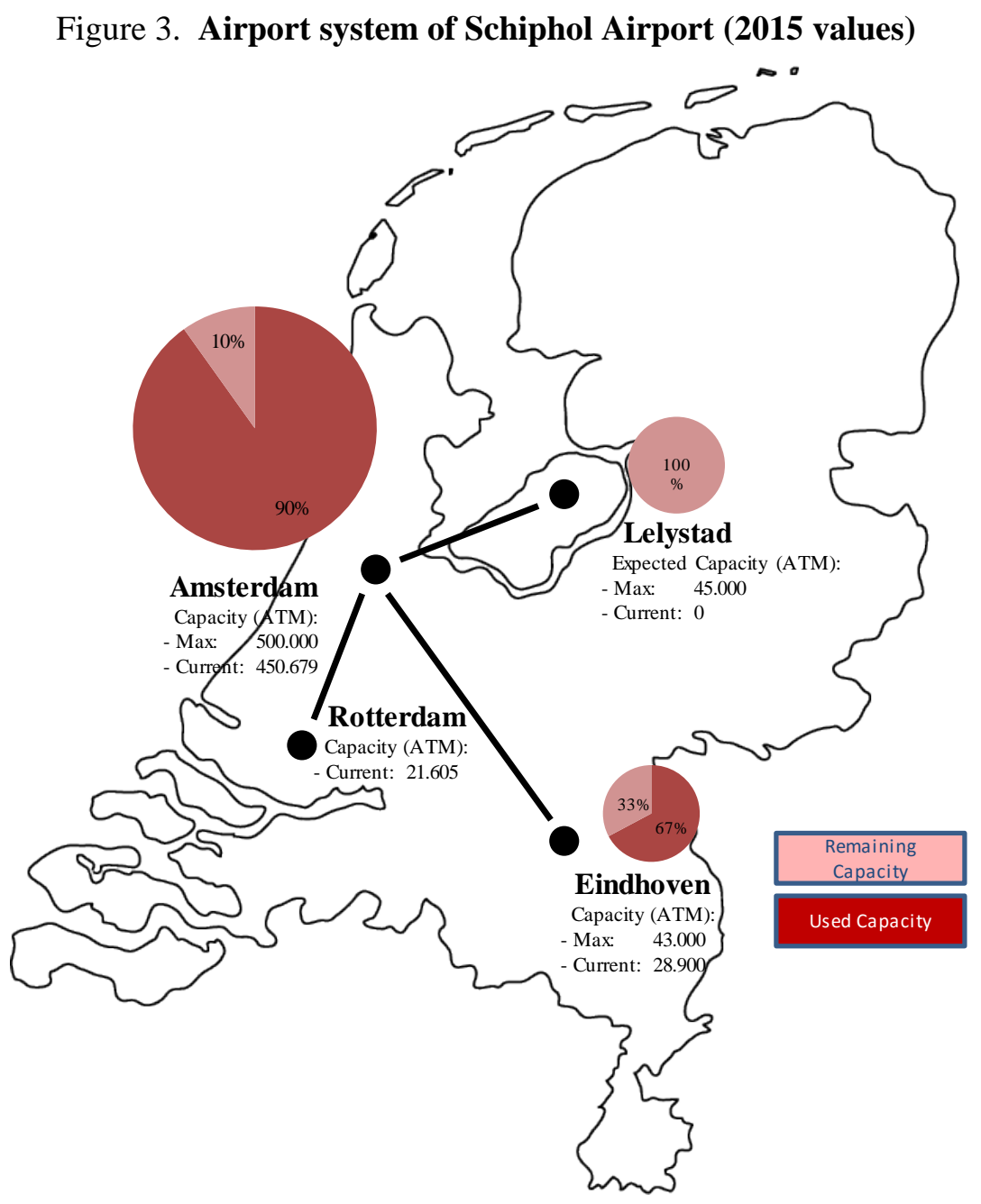

Source: Mujica Mota et al. (2017).

Limitations due to noise cause not only a maximum number of ATM per year but they also add complexity on the airport operations, especially for air space usage in the terminal ATC area. In practice ATC has to decide what runway should be used by arriving and departing flights based on time of the day and available noise quota left from the annual noise budget per runway.

Additionally, the strict arrival and departure paths offer further challenges for ATC controllers and pilots. At night times the Polderbaan (see Figure 1) is the preferred runway due to its remote location 
away from the houses. This procedure requires an additional 15-20 minutes taxi-time (relative to other runways at Schiphol) due to the distance between the runway and the terminal building. Overall, due to the established relationship, airlines and airport are confronted with a situation in a complex airfield in which the runways configuration must be changed during the day making the management of traffic a real challenge. This in turn affects the potential capacity of Schiphol.

Assuming a constant noise budget, being the maximum amount of noise to be produced at any location on the contour per annum, the amount of ATM is by definition a function of available technology and operational procedures. Therefore, the quieter the aircraft used at Schiphol, the more accurate use of arrival and departure paths, the more efficient scheduling for flights between day, evening and night, the more ATMs can fit within the given contour.

Another consequence of the noise contours, preferential runway usage and the introduction of the Polderbaan for evening and night flights is that Schiphol dominates/controls the land-use of a vast land area around the airport as shown in Figure 4.

Figure 4. Noise contours around Schiphol Airport

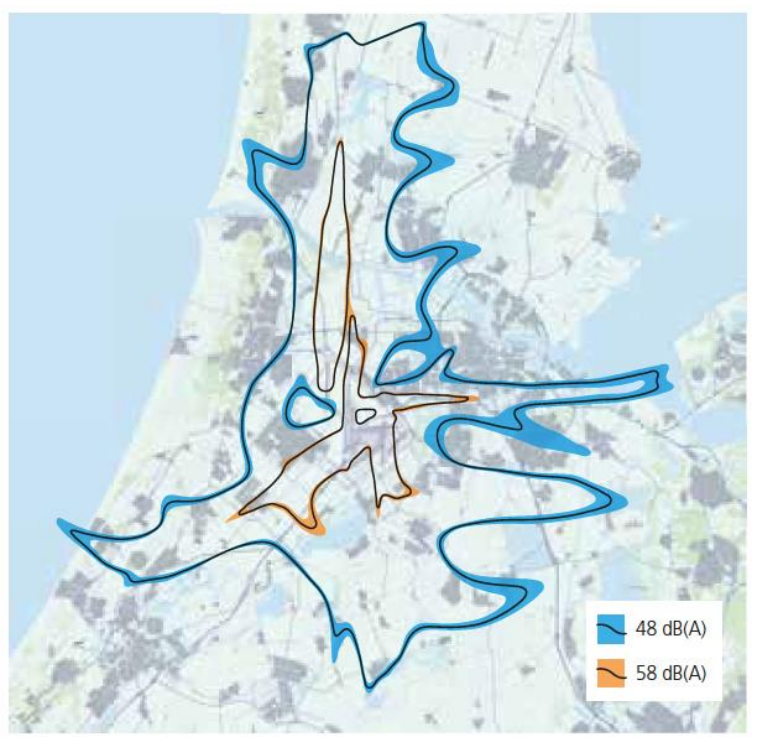

Source: Schiphol Group (2015).

Next to noise contours, the neighbouring communities and cities are also confronted with safety zones and land-use for land transportation to and from the airport. Due to its runways layout, Schiphol Airport has a large land area (2787 ha) compared to, for instance, Heathrow Airport (1227 ha) (Janic, 2016).

\section{Physical boundaries}

Available land on- and off-airport offers limitations for airport development. Given the land scarcity in Schiphol surroundings there is a big pressure from area neighbouring communities to redevelop land for housing and business areas. The current land occupation for noise and safety contours and corridors for land traffic connections to the airport block this development. It results in a so-called Schiphol Paradox: the more successful the airport development and its contribution to the regional economy is the more constrained the airport growth by neighbouring communities will be, which are directly beneficiaries of housing an economic development result from the airport development (Boosten, 2008). 
The airport has a large impact on the development and land use planning of the region. Most communities and cities surrounding the airport face serious limitations to expand, nature and precious habitat are effected by aviation, quality of living of large areas are impacted by noise, pollutants, safety zones and land-based traffic corridors which are often very congested due to local and airport designated traffic.

Environmental constraints in combination with land use put severe pressure on the maximum annual capacity of Schiphol Airport. Given the fact that the technical capacity is still not reached, there is an on-going debate if the boundaries of the airport are too strict. In 2020, the Schiphol advisory board will review the situation in order to decide if newer technology would be applied and some capacity can be relieved to Schiphol and also to the community in the form of a reduced noise cap. The solution for short- and medium-term growth was found in establishing a multi-airport system where the regional airports are used as reliever airports for Schiphol.

\section{Box 2. The concept of the multi-airport system}

The multi-airport system is defined as an informal system with no hard regulation to allocate air traffic to various airports. The government uses soft incentives like prices to convince airlines to move from Schiphol Airport to other airports in the system. The lack a hard criteria now puts pressure on the sector and the government because no party is willing to move and the non-hub airlines fear hard measures by the government to force them to move. The government on the other hand struggles to find the right set of measures. Up to now spill-over to other airports is a capacity measure that has not worked. (Cohen, 2017b)

\section{Airline and airport business models}

The business models of an airport and airlines impact how much physical capacity is available and how it is used. The business model of an airport has changed nowadays. Modern airport enterprises have diversified by enriching service package offering (Jarach, 2005). The core benefits of an airport are the passengers and goods transferred, the generic product that includes the airline and airport services, the expected product including multi-modal services to and from the airport and the wide product including logistical, commercial, consulting, real estate services among others (Jarag, 2005). So the revenue is not coming only form the core business handling aircraft and passengers or cargo in terms of airport fees, today it also comes from non-aeronautical businesses inside the airport (retail and food and beverage), car parking, real estate management, and business locations inside the airport among others. We can see good examples of these new business models in the biggest hubs in Europe and abroad, people can perform diverse activities inside the airport which include shopping (BCN, CPN), to visiting museums and casinos (Schiphol), and even surfing in summer (MNC). At Schiphol the airport business model has a high interaction with developments in the region (Figure 5). The airport connectivity supports the business development in the region and this in turn will increase the demand for connectivity and traffic.

The Schiphol business model is based on exploiting a so-called airport city concept. In this model an airport invests in both aeronautical and non-aeronautical activities and the overall airport return is based on the revenue flows from both activities. Within the airport company this will result in constant debate on where to invest the scarce capital. Delaying investments in operational capacity (the concept of sweating assets) is beneficial in the short term for the airport financial results, especially if there are good options to invest in (very) profitable non-aeronautical activities. On the other hand, expanding non-aeronautical activities at the airport does have an adverse impact on the landside capacity of the airport. It attracts more activities and traffic to the airport that has to be accommodated next to the dedicated air traffic (passengers, cargo and staff). 


\section{The AirportCity Growth Cycle}

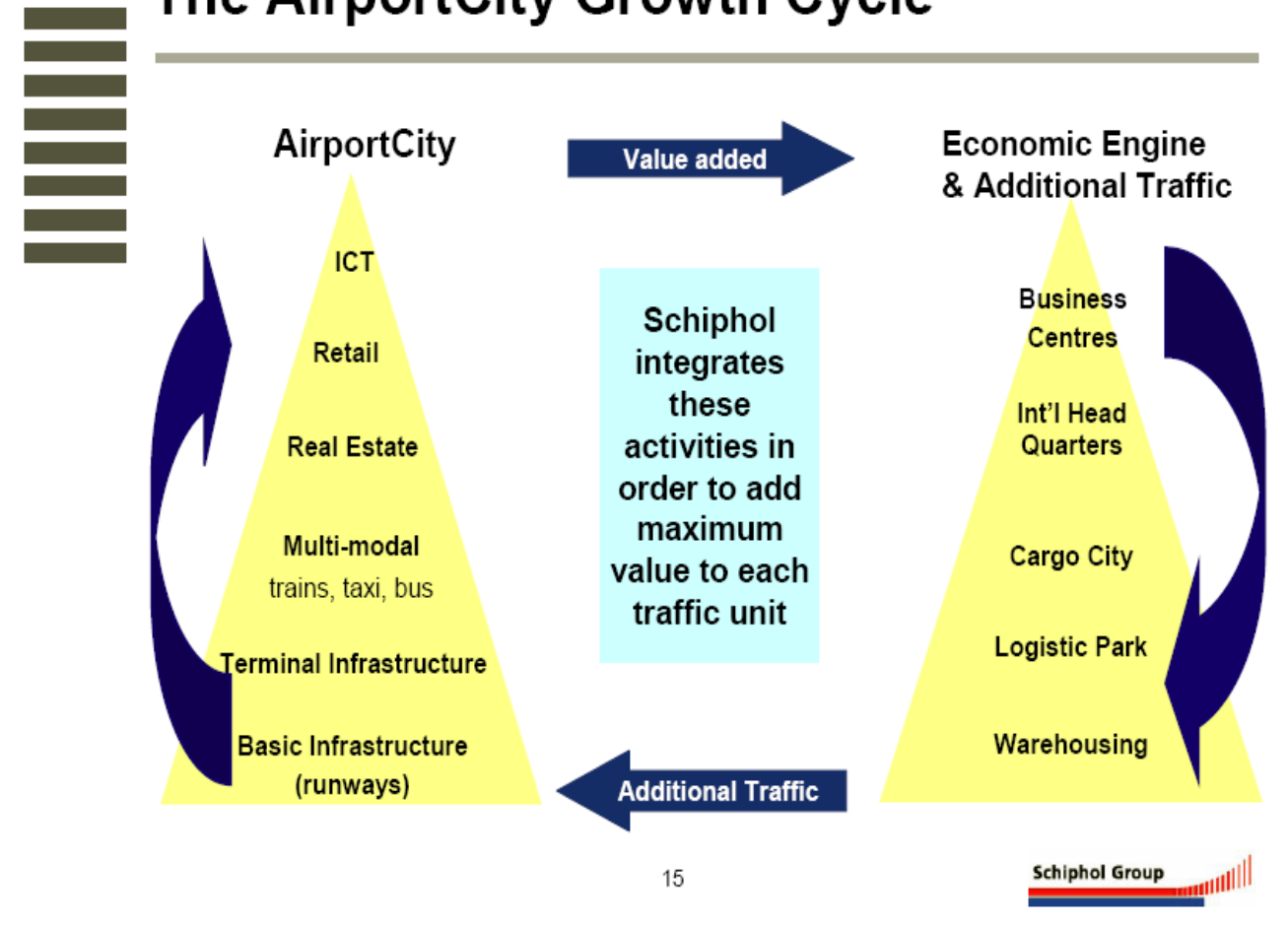

Source: Schiphol presentation

Due to the required time for expanding facilities, it can only be done stepwise and In this case the airport takes the economic risk on the investment. The structure and business model of the airport will in turn provide answers on the question of if the airport is capable to invest in capacity expansion programmes (either new infrastructure or optimisation of existing). Schiphol Airport is a state-owned company that has direct access to the financial markets; before the financial crisis in 2008 the airport had a AAA-status and in 2016 the airport has an A1-status. ${ }^{4}$ Until now Schiphol has been able to invest in new capacity timely and was able to get a positive return on its investments. The new status of Schiphol implies that more risk is put into the investments therefore they have to be evaluated carefully in order to avoid potential economic downturns. This in turn may cause that investments in airport capacity expansion will be delayed or limited therefore new capacity will be available at a later stage.

Airline business models in turn have an impact on how and to what extent the capacity is used. At Schiphol Airport, the home carrier KLM and its alliance partners count for approximately $70 \%$ of the traffic and most of the transfer traffic. KLM and partners operate a hub concept at Schiphol, resulting in high operational peak demand and need for evening, night and early morning flights. Just like many carriers, KLM's business model is based on frequency competition using smaller aircraft by generating high frequencies of service to the same destination. This principle demands much more peak capacity than the situation of an airline maximising the number of passengers or cargo per movement (D'Alfonso and Nastasi, 2014). At Heathrow, due to severe capacity constraints British Airways makes a different choice by using larger aircraft with less frequent flights than Schiphol (D'Alfonso and Nastasi, 2014) making a more efficient use of the work load units per movement ${ }^{5}$. 
The second group of big users at Schiphol are low-cost carriers (LLCs). The LCCs typically operate A320 or B737 family-type of aircraft at a high frequency to several destinations as well. Because of these operational models, airlines (no matter if it is FSC or LCC) prefer certain times of the day to fly putting high pressure on these slots while other times in the day the facilities are underutilised.

As a hub, Schiphol Airport competes with the other major hubs in Europe. The airport thus has incentives to be able to provide high peak-capacity as well as reliable, short minimum connection times (MCT). These features allow the hub carrier to offer high connectivity with short transfer times at the airport. The overall capacity and efficiency of the hub can be defined by its maximum peak hour capacity (measured in ATMs) which has bearing on the number of available connections offered by the hub and by its ability to transfer passengers and baggage between flights within the requested MCT. The terminal design and automated baggage handling system are supportive to this capacity demand. Furthermore, at Schiphol both the "one-roof-terminal-concept" and the massive investments in automated baggage handling systems are developed to support the peak hour transfer capacity demand. All these features make the airport very attractive for supporting the business models of the different carriers that want to operate in it.

In addition, traffic flows are shifting worldwide; for instance, the airports in the Middle East nowadays connect Asia, Australia and the Americas. For Schiphol Airport, these trends could have a major impact in the demand for and the type of airport facilities needed. Scenarios are possible that the existing capacity and business models will be completely restructured. Due to these situations, continuing to optimise the current capacity and operations might not be possible.

\section{Box 3. The impact of long-haul low-cost business model}

A recent report indicates that the introduction of long-haul low-cost (LHLC) operations at Schiphol might introduce passenger self-transfer. The passenger itself books two connecting flights at his own risk and ensures the connection of the baggage. Airports like London Stansted and Milano nowadays start facilitating this type of transfer. But it will require new infrastructure at the airport and will result in facility changes at the reclaim areas and transfer lounges among others. (KiM, 2017)

\section{Relationship region-airport}

The main objective of the hub airport in Amsterdam is to support the regional and the national economy by delivering connectivity to all important regions in the world. It acts as an economic engine for the region. Therefore, for the development of the airport, a careful balance is required between the national/regional (economic) interests and the business development of the airport and airline. For some decades, a relationship between the airport, government and the main carrier (the triple helix) acted as the major driver for airport development in the short, medium and long term (see Figure 6). Through this relationship, the airline and airport had congruent strategies towards the development of the region and the country.

The airport generates many jobs locally, supports economic activities in the region and offers inhabitants high levels of air connectivity. These high levels of connectivity, on the other hand, are supported by transfer passengers who could have, at least in theory, the option to use other airports to reach their final destination. Furthermore, in the light of capacity constraints at Schiphol, the recommendation of the advisory board for Schiphol is to redistribute the non-hub-related traffic to other airports in the Netherlands. If airlines, particularly LCCs, have to move to a different airport, this might bring as a consequence that some local travellers in the vicinity of Schiphol will have to use another airport to get to their destinations. Furthermore, in the extreme case Schiphol will be left as a hub airport 
for airlines that match this business model. Additionally, noise and congestion can be displaced to other areas of the country.

The Dutch economy is an open economy with a high-connectivity demand to support the country's exports where transportation and logistics are important economic sectors. KLM's strategy is focused on becoming a worldwide operating carrier as a partner of a large alliance; the airport strived to become a "mainport"" for the Dutch economy and an important hub for the national airline. This relationship where the national and regional interests are put on top of the priorities raise a debate about what the right limit for the airport should be. This limit should aim at finding the right balance between its position in the Dutch economy as a node in the global economic network and the quality of life in the Amsterdam region.

\section{Figure 6. The triple helix as growth model for Schiphol Airport}

\section{The Original growth model: \\ Amsterdam Airport Schiphol: cooperation}

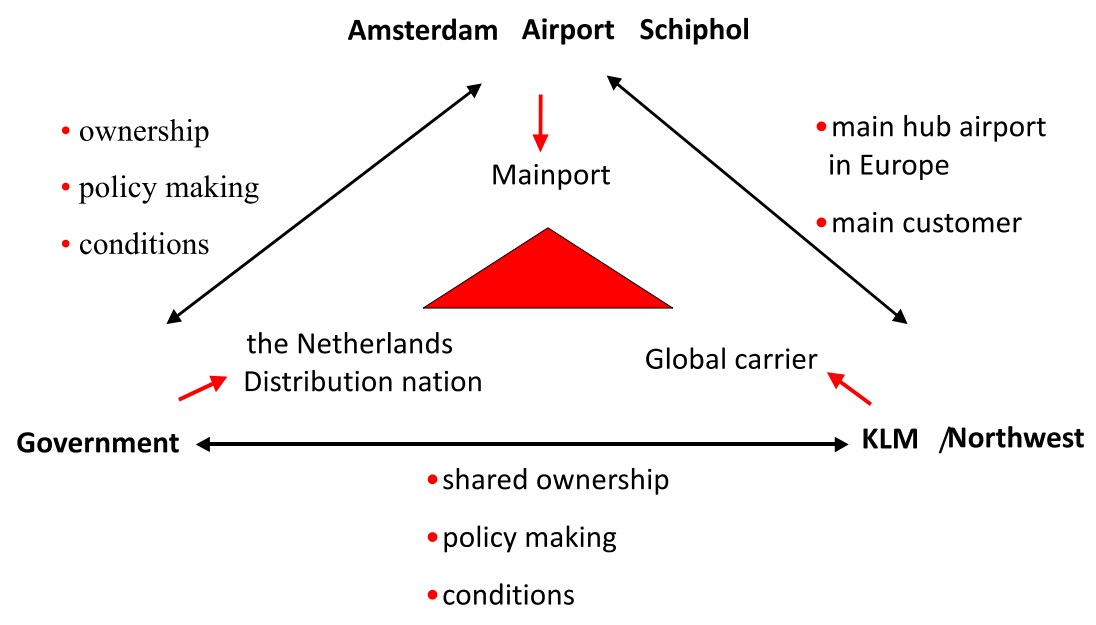

Source: AAS presentations.

Interviews with former executives showed that the triple helix was detrimental to the success of both the airline and airport by comparing Schiphol's growth model in the 90's to Frankfurt Airport Fraport and Copenhagen Airport (Veer and Bertnsen, 2016).

The business/development models of the Dutch Government, KLM and Schiphol Airport are key parameters for the airport capacity as a whole. Within the framework of the environmental capacity, parties cooperated to create the maximum capacity of a successful hub. With this objective in mind, airside, terminal and landside capacities are balanced based on the aviation demand and the further commercial development of the airport city concept. It is important to note that at Schiphol the airport capacity is not only a function of aeronautical activities at the airport; capacity for non-aeronautical activities is required to finance the investments in infrastructure, to attract business to the airport and to secure connectivity to all regions worldwide. 


\section{Rules and regulations in Schiphol}

Regulation of airport capacity can have significant influence on the operational capacity of the airport. For instance, a night curfew will have a big impact on the airline flight schedules and operations. It could result in change of peak patterns if airlines try to optimise its aircraft utilisation or even relocate aircraft to different airports to avoid flights that cannot depart or arrive on time before the curfew. Such changes may also affect the efficiency and on-time performance of the terminal operations.

Changes in security regulation affect the throughput of both passengers and baggage. Recently Schiphol Airport had to invest heavily in upgrading security due to the aftermath of the terrorist attacks in Brussels and Istanbul. In addition, a new round of measures and investments pertaining to landside security are foreseen. Moreover Schiphol serves significant traffic to and from the UK thus Brexit may imply that the terminal will be redesigned to account for a higher share of non-EU traffic passing through the airport. Altogether these events and changes in security will affect the capacity of the airport and possibly change the balance between airside and terminal/landside capacity. This can result in longer handling times within the terminal which will increase the minimum connecting time between flights and thus reduce the peak hour connectivity. For this reason Schiphol is also working on new high throughput security units based on biometrics.

\section{Societal considerations}

For the airport, the questions of scale and scalability arise. There is a concern that further growth of air traffic and the resulting additional airport facilities, which is technically possible, may not be beneficial to airport operations. It can take up to two hours or more to walk from the landside to the gate, suggesting that there might be a limit to the capacity of an airport site. So in these situations the expansion of facilities for increasing capacity might discourage the use of Schiphol to some passengers.

Regarding social and technological developments, apart from having a direct impact on aircraft operations, they also influence human behaviour inside the airport. Its impact it is not totally clear yet. On the one hand we can already see that travellers use smart technology to make their own well informed decisions and the time they spend in the airport might be affected by the use of novel technology. On the other hand, technological developments pertaining to communications also change the way in which individuals and businesses decide whether to travel or communicate from home or workplace before travelling. The use of easier ways of communicating may indeed intensify air travel through fostering connections that haven't been previously possible.

\section{Summary on capacity situation of Schiphol Airport}

The capacity of Schiphol Airport cannot be defined by one single parameter; to define the capacity is a complex matter of very different non-independent parameters which via iterations can influence each other. For the moment the most influential factor is the triple helix relationship between Dutch governments, airline and airport which imposes an artificial ATMs/year cap due to the problems noise cause to the population in the vicinity of the airport. In addition, other important constraints and factors that affect the potential growth of Schiphol Airport are:

- Technical constraints: The technical peak hour capacity is measured in the maximum hourly ATMs and handling capacity of terminal and landside in millions of passenger/annum combined with the level of service standard if no other limitations would occur. This peak hour capacity is based on the available infrastructure and use of air space. The combination of runway capacity with airspace capacity will determine the operative limit of the airside while the size of facilities and technology in place will determine the amount of passengers that can 
be handled per hour. For the time being, the technical capacity for Schiphol is not the most limiting factor.

- Environmental constraints: The environmental capacity being the annual limitation of the ATMs to reduce the annoyances caused by the airport to the environment and population. As mentioned before the most limiting factor is the amount of noise produced per annum per point on a noise contour. The environmental capacity can be further limited by other conditions like emissions or safety. Currently noise restrictions limit the number of ATM per annum to 500000 and this limit is in 2017 the constraining factor for slot allocation.

- Airport and airline business models: They define how airport capacity will be used. The hub development at Schiphol Airport is very important for the region, therefore the routing of traffic to reliever airports or the modification of strategies from high frequency to improvement of WLU per ATM play an important role for defining the capacity of the airport. There are difficulties to execute these options because of the lacking of instruments to distribute the traffic between the airports.

- Infrastructure: The relationship between airport and airline play an important role for defining when expansions will take place and who runs the risk. For the moment Schiphol runs the risk for these investments and this could result in a policy of sweating assets and delay aeronautical investments as long as possible. Consequently, it might affect the operational capacity of the airport and/or delay the investments in airport facilities. Currently Schiphol is investing in a new pier with eight gates for absorbing the demand (A-pier).

- Relationship (the triple helix): The relationship between Dutch governments, airline and airport was a unique and important key for the successful development of the hub and airport capacity in the region. Once Schiphol reaches its annual capacity limits, new ways for interaction with surrounding communities and tools to balance the impact of airport growth in the region should be developed. In other words solutions for further expansion could be found outside the airport perimeters.

- Technological developments: New socio-technological trends can influence the traffic and/or hub developments as well as the behaviour of passengers and cargo at the airport. Airport usage and utilisation can change dramatically due to these developments with a major impact on capacity requirement. For Schiphol Airport we already can see some trends emerging like new transport flows worldwide, smart personal technology being used to optimise the operational processes and commercial activities. In future dwelling times of passengers and cargo at Schiphol can be reduced with a large impact on the business model while the use of telecommunications tool will foster the use of airlines.

- Government regulation: New rules and regulations can have a major impact on the peak hour capacity or capacity at specific times of the day. Schiphol security and border control will impact the capacity for transfer passengers within the MCT and therefore the efficiency of the hub and the capacity needed for ATM and handling times.

- Congestion and delay in the network: For an airport operating at maximum capacity in most partsof the day, it will take long time to recover from delays or other disturbances. The impact might be strengthened due to the main traffic flows between hubs and also the delays might be distributed amongst the hubs in Europe. Schiphol is part of the European network and has declared a high operational capacity; the traffic growth will make it increasingly difficult to 
keep its performance in practice as declared. We should add a recovery standard (or resilience measure for brittleness) to the airport capacity indicators for getting an indication of its vulnerability to disturbances and the time needed to recover.

\section{Mexico City Airport}

In 2015, Mexico transported more than 73 million passengers and about 655500 tonnes of cargo. There were 63\% domestic passengers and 37\% international passengers. Mexico City International Airport moved 38.43 million passengers, more than a third of the total traffic of the country (SCT, 2015), which makes it the major airport in Mexico and one of the most important airports in Latin America. In the cargo sector, it moved almost 33500 tonnes from which 27600 tonnes where from international destinations and 5700 domestic ones. This makes it the main airport for international and domestic cargo controlling the $65 \%$ and $38 \%$ of the total, respectively. The domestic general aviation sector accounted for the $8.5 \%$ of the total movements. In addition, the demand will continue to grow in the coming years (around $+5 \%$ in aircraft movement and $+12.2 \%$ in number of passengers) and 41 million passengers have been forecasted by 2020 .

\section{Airport infrastructure}

AICM runway system consists of two runways with dimensions of $3963 \mathrm{~m} \times 45 \mathrm{~m}$ and $3985 \mathrm{mx} 45 \mathrm{~m}$, respectively. Runways operate in a segregated mode which means that one is used for arrivals and the other one for departures. According to Herrera (2012), the arrivals are performed on the runway $05 \mathrm{R} / 23 \mathrm{~L}$ and departures on runway 05L/23R. The current airport facilities have a total surface area of 790 ha. It includes 96 parking positions, 33 direct boarding gates in Terminal 1 (T1) and 23 in Terminal 2 (T2), and a total of 74 operative gates. AICM accounts for two passenger terminals, T1 with $548000 \mathrm{~m}^{2}$, and T2 with $242000 \mathrm{~m}^{2}$ which are interconnected by a $3-\mathrm{km}$ monorail and road access. T1 is used for both national and international flights, whereas T2 is used mainly operated by Aeromexico and its allies. The airport can be accessed by subway, bus, taxi and private transport. It also connects directly with more than 5000 car parking spaces split between the international and the domestic area. Figure 7 depicts an aerial view of the airport. 
Figure 7. AICM airport model layout

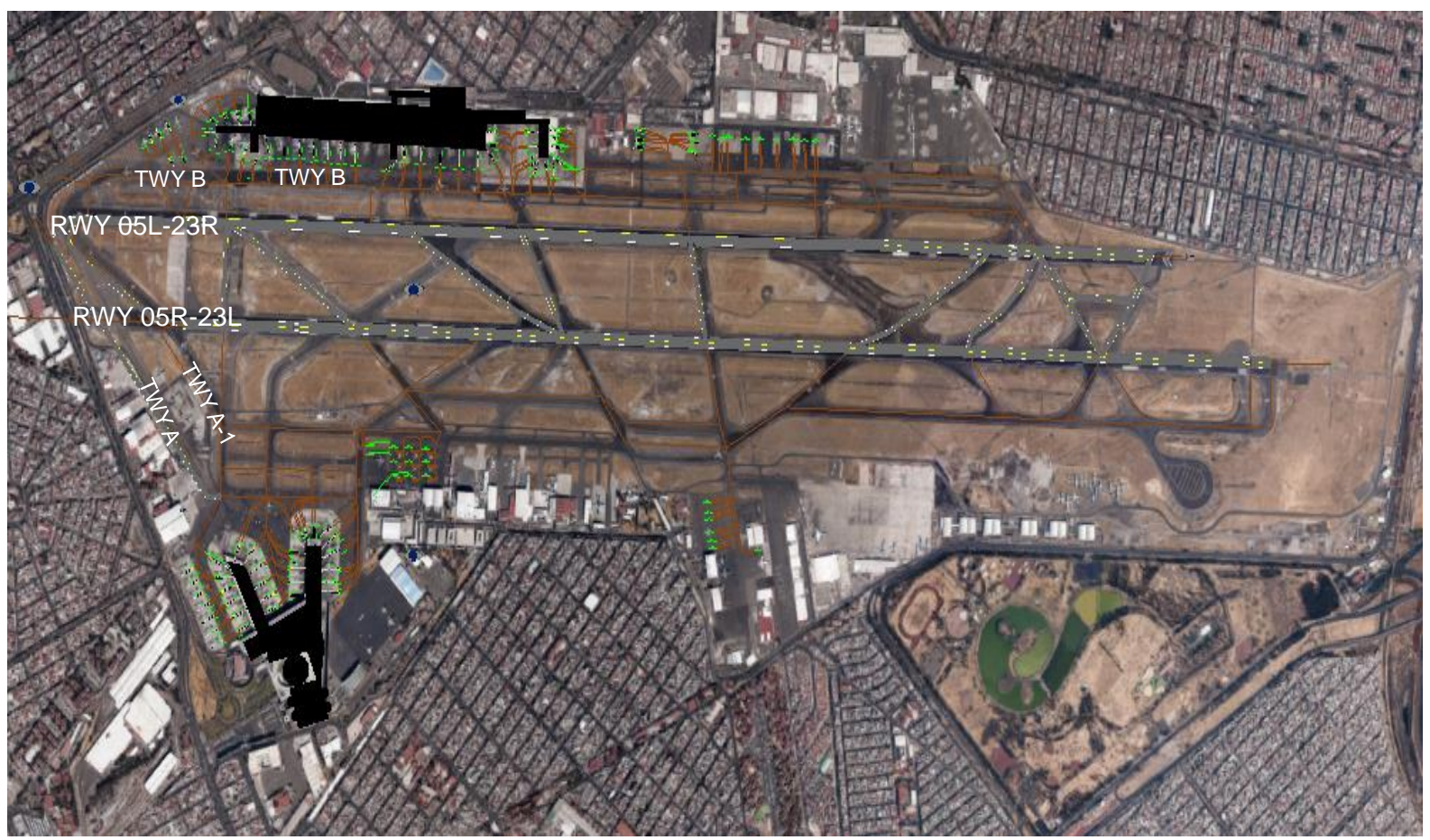

\section{Environment constraints}

As in the case of Schiphol, AICM is also contained by factors such as noise emissions that force particular air space usage rules; those in combination with its altitude (2230 AMSL) make the operation a challenge for ATC. Furthermore, rules for runway system availability and usage are also influenced by weather conditions, when the wind is from northeast; landing operations are usually directly over the urban area. Therefore, there is an important problem regarding noise pollution. This issue has been partially mitigated by the introduction of new aircraft models with advanced technology which reduces noise emissions and fuel consumption. Normally, at AICM, aircraft use the take-off/climb noise abatement procedures provided by the aircraft flight manual in coordination with ATC.

\section{Physical boundaries}

The airport is located on the east side of Mexico City but in the core of metropolitan area: it is located in a 25 -million inhabitant metropolis situated $5 \mathrm{~km}$ east downtown and surrounded by a huge urban area. Nowadays, the airport does not have a clear possibility of expansion in terms of available land on and off airport. The geographic characteristics of the airport also affect its capacity; it is located at an elevation of 2230 AMSL, which complicates landing and departure operations. In addition, it is surrounded by volcanoes and mountains in a convection zone. Its runways run southwest-northeast, which constrains the approaching and departure routes. In addition, the soil conditions of the airport with high water content pose extraordinary challenges mainly in runways and terminals. These environmental constraints in combination with operations put severe pressure on the maximum operative capacity of the airport. 


\section{Airline business models}

The airport is used by 26 commercial airlines and 17 cargo carriers. Aeromexico, the biggest Mexican airline, has its operation hub in the airport, and as the airline belongs to the Sky-Team alliance, the airport has also become a Sky-Team hub. AICM serves as the major hub airport in the Mexican system; it has the highest connectivity origin-destination routes within Mexico. It has been accounted for 750 regular routes, 402 international and 348 domestic routes. Table 2 and 3 introduce the top 10 domestic and international routes respectively.

Within the domestic routes, 47 concentrate the $80.2 \%$ of the total passengers; while the $80 \%$ of the international tourism uses 94 routes (SCT, 2015). In the international sector, most of the passengers come from United States; this could be linked to two main factors, the first one is the alliances between airlines and the currently used hub and spoke model of airports; and the second being the big amount of Mexican population living in the US. Aeromexico transported in 2014 the biggest amount of passengers to United States with a total of 2.8 million, followed by Volaris with almost 1.7 million. To Europe, Asia and Canada, Aeromexico was the only airline which transported passengers, a total of 384000,120000 and 83000 passengers were accounted, respectively. To Central America and the Caribbean, Aeromexico, Aeromexico-Connect and Interjet transported 196 000, 235000 and 270000 passengers, respectively. To South America, there were transported by Aeromexico and Interjet 88100 and 76000 passengers, respectively (SCT, 2015).

\section{Table 2. Top 10 domestic routes in México}

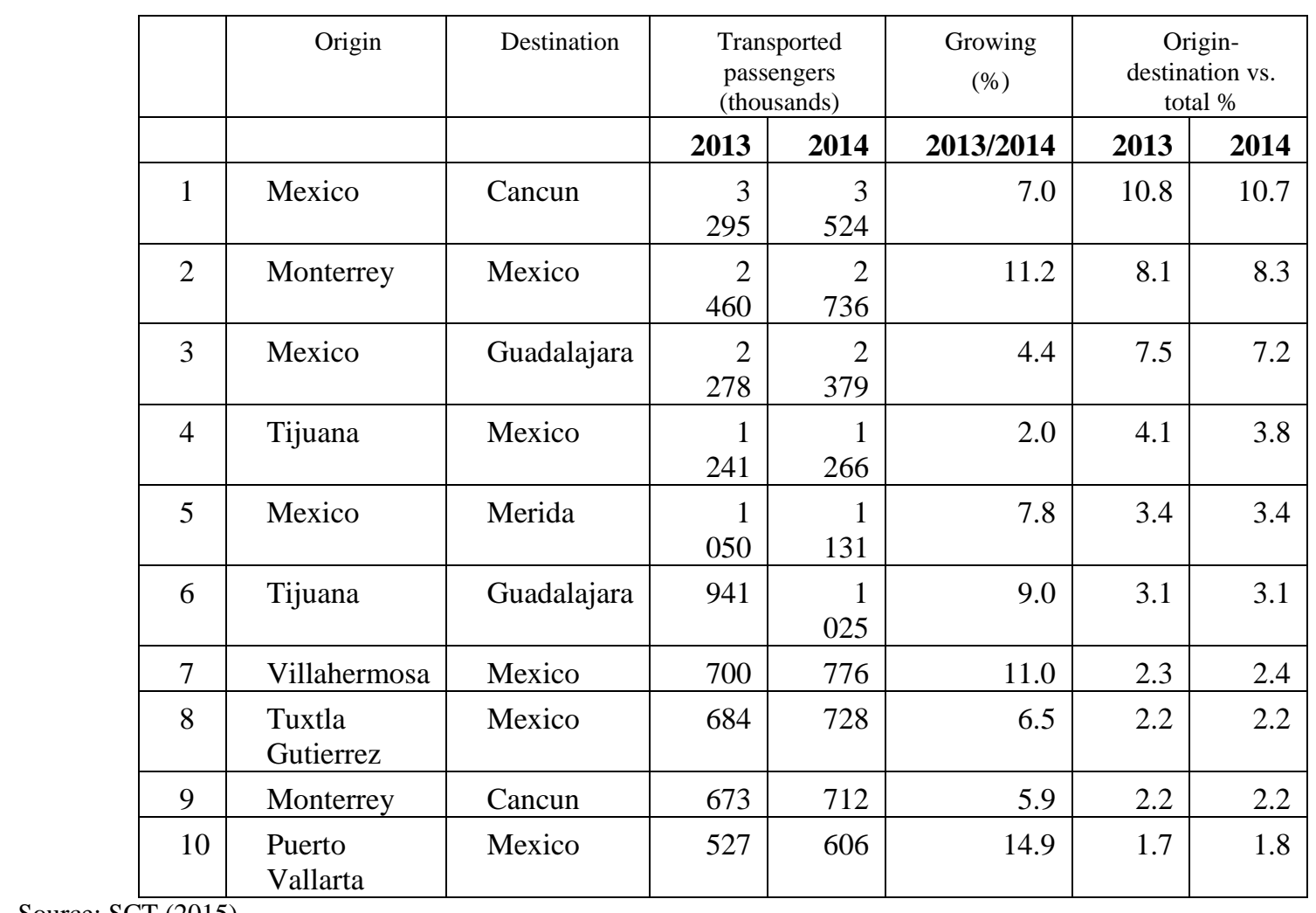

Source: SCT (2015) 
Table 3. Top 10 international routes in Mexico

\begin{tabular}{|c|l|l|c|c|c|c|c|}
\hline & Origin & Destination & \multicolumn{2}{|c|}{$\begin{array}{c}\text { Transported } \\
\text { passengers } \\
\text { thousans) }\end{array}$} & \multicolumn{2}{|c|}{$\begin{array}{c}\text { Growing } \\
(\%)\end{array}$} & \multicolumn{2}{|c|}{$\begin{array}{c}\text { Origin-destination } \\
\text { vs. total \% }\end{array}$} \\
\hline & & & $\mathbf{2 0 1 3}$ & $\mathbf{2 0 1 4}$ & $\mathbf{2 0 1 3 / 2 0 1 4}$ & $\mathbf{2 0 1 3}$ & $\mathbf{2 0 1 4}$ \\
\hline 1 & Mexico & $\begin{array}{l}\text { Los } \\
\text { Angeles }\end{array}$ & 783 & 813 & 3.8 & 2.7 & 2.5 \\
\hline 2 & $\begin{array}{l}\text { New } \\
\text { York }\end{array}$ & Cancun & 731 & 803 & 9.8 & 2.5 & 2.5 \\
\hline 3 & $\begin{array}{l}\text { Los } \\
\text { Angeles }\end{array}$ & Guadalajara & 746 & 781 & 4.7 & 2.5 & 2.4 \\
\hline 4 & $\begin{array}{l}\text { New } \\
\text { York }\end{array}$ & Mexico & 710 & 760 & 7.2 & 2.4 & 2.4 \\
\hline 5 & Cancun & Atlanta & 661 & 704 & 6.6 & 2.2 & 2.2 \\
\hline 6 & Miami & Mexico & 718 & 694 & -3.4 & 2.4 & 2.2 \\
\hline 7 & Mexico & Houston & 620 & 693 & 11.7 & 2.1 & 2.1 \\
\hline 8 & Dallas & Cancun & 630 & 678 & 7.7 & 2.1 & 2.1 \\
\hline 9 & Houston & Cancun & 561 & 585 & 4.3 & 1.9 & 1.8 \\
\hline 10 & Mexico & Bogota & 469 & 572 & 21.9 & 1.6 & 1.8 \\
\hline
\end{tabular}

Source: SCT (2015)

However, due to the restriction in capacity, it has become difficult for airlines to get slots to operate at AICM. According to OCDE (2014), the AICM's slot allocation process is one of the major hurdles for airline competition, the claim by the government is that airport is fully used and thus competition by new entrants is restricted. In 2013, the Ministry of Communications and Transportation (SCT) issued a new Saturation Declaratory for the Airport (DOF, 2013). According to Mexican authorities, the maximum capacity is limited to 61 operations per hour (with hard restriction of 40 landings per hour) under optimal conditions. However, during adverse weather conditions the limit will drop to 30 or even 20 landings per hour.

The consequence of AICM being constrained is that traffic at regional airports bound for AICM suffers delays (ground delays) due to ATC problems at AICM. The result is increasing delays in the domestic aviation system and underutilisation of aircraft by the airlines. Therefore, the need has been expressed to design and implement an efficient slot allocation model based on competition, in order to benefit consumers and stakeholders by increasing new competitors and its participation in all the airport system.

According to data from SCT (2015), the biggest domestic airlines in terms of transported passengers are Aeromexico, Volaris, Interjet and Aeromexico-connect. In Mexico, the low-cost carriers (LCCs) business model arrived in 2005 with $5.5 \%$ of the market share and fast growth allowed them to get up to the $60 \%$ of the domestic market by 2013. This sector is operated by three main companies (Interjet,Volaris and Vivaaerobus). Unlike these companies, there has been limited development of LCCs, while the potential in the market is clearly there (see Figure 8). 
Figure 8. Low-cost carrier behaviour in Mexico

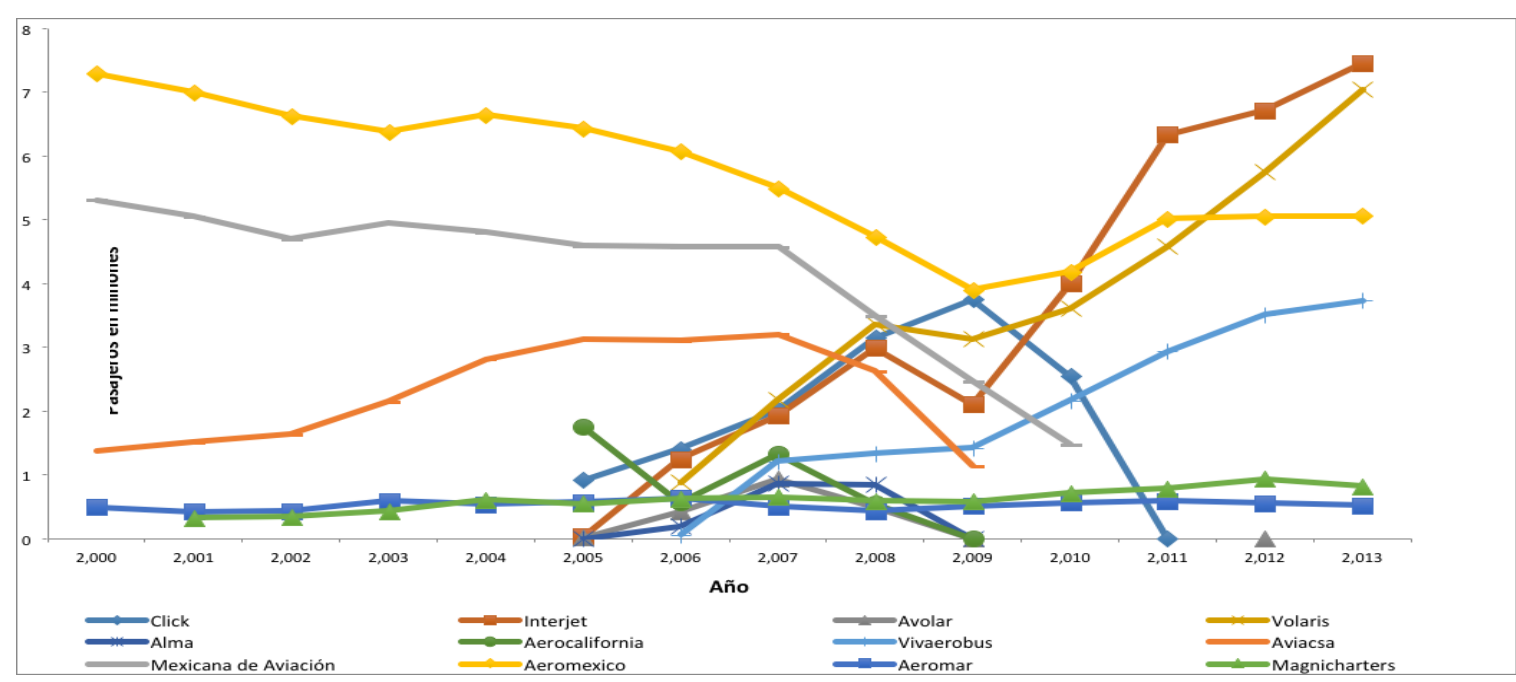

Source: SCT (2015).

\section{Relationship region-airport}

Similarly with Schiphol, innovative alternatives have been explored in order to provide efficient and reliable services for the metropolitan region. One of them involved implementing new demand management schemes which involves the development of a multi-airport system. To do so, the catchment area of the metropolitan region was analysed taking into consideration the social, geographic, economic, and political reality of the different zones. As a result, Mexico City airport is the main airport and the airports of Queretaro (QET), Toluca (TLC), Puebla (PBC), and Cuernavaca (CVJ) airport are also considered within the multi-airport system.

\section{Relationship airport-airline}

AICM as many airports in the world, operates its terminals with operative and commercial rules. Terminal 1 is used by many carriers for domestic and international flights, and it is used to handle different types of aircraft ranging from A320s to A380s in a dedicated gate. Terminal 2, which is the newest terminal, is mainly operated by Aeromexico, and its twenty allies from sky team provide access to 1062 destinations in 177 countries. As a result, with new destinations and new routes offered, Aeromexico operates more than 600 daily flights and its destinations network features more than 80 cities: 45 in Mexico and 41 in America, Europe and Asia (Aeromexico, 2015). Among the benefits of the alliance, the member airlines can benefit from knowledge and best practice sharing, particularly when it comes to safety, customer service and operational efficiencies.

\section{Governmental regulations}

In 1997, Mexican government opened the inversion to the airport systems. As a result, five airport groups manage 35 out of the 60 airports. Grupo Aeroportuarios Ciudad de México operates the AICM, while, Grupo Aeroportuario Centro Norte holds thirteen airports and Grupo Aeroportuarios del Pacífico twelve. Aeropuertos del Sureste accounts for nine airports while the rest remain operated by the government under ASA Corporativo. The conformation of these groups, together with liberalisation and deregulation, has been employed in order to facilitate access to competitors and increase capacity. 


\section{Societal behaviour}

An official public announcement in 2001 declared the needed for the construction of a six-runway airport on communal lands a few kilometres east of the AICM. The project was meant to become an achievement to the Mexican Air Transport system; the airport was projected as the new gateway to Latin America. However, the decision failed to acknowledge local and regional impacts, particularly in terms of the required expropriation of 15000 acres belonging to communities living in the surroundings. It was necessary to relocate thousands of families who have lived and work for decades in the area. Communal farmers refused to abandon their lands. In reaction, the government offered farmers a modest compensation (around USD 0.70/m2) for the land (Galland, 2011). This became a strong social movement against expropriation which produced constant protest marches and a series of unfortunate and violent events and confrontations. After this situation, and followed by unsuccessful negotiations, the federal government decided to cancel the project. Decision makers and managers failed to predict this scenario was perhaps due to the complex behaviour between socio-economic, biophysical, political and cultural contexts.

\section{Technical constraints}

As it has been mentioned, the airport suffers mainly by technical constraints. These are mainly due to the separation between runways (approximately $300 \mathrm{~m}$ ) which does not allow for independent operations. Instead both runways are operated following the ATC rules for parallel dependent operations in which most of the time one runway is used for arrival while the other for departures.

In order to exemplify that for some factors different tools or mechanisms can be applied for increasing or understanding capacity problems; the following section illustrates a simulation-based analysis that allows identifying the main blockers of the system and the impact of the change in technology by using bigger aircraft as the A380 in such a constrained system.

\section{Identifying potential for growth by a simulation-based analysis}

A simulation model was developed in order to analyse the performance of the airside of the airport, aiming at identifying the bottlenecks during the operation of a high-demand day. The model simulates the movements over a 24-hour period; based on a publicly available flight schedule of the airport (OAG, 2015).The flight schedule of a representative day has been used as the main input for the model which was validated using information from Flight Stats and Flight Radar (Flight Radar, 2017).

The simulation model incorporates the uncertainty of the operation of the problem such as variation in turnaround times and taxi times, among others. The level of detail enables the integration of technical and operative restrictions imposed by the airport authority and ICAO. The most relevant characteristics are the wake vortex ${ }^{6}$ and taxiway separation, taxiway routing for landing and take-off, and the routes followed by the aircraft in the taxiway network. Aircraft speed and type have also been modelled in each of the taxi in/out route together with the stand location and quantity.

The elements that compose the complete model are: the two runways, taxi network and parking stands for the two terminals (T1 and T2). The model focuses only in the airside operation of the airport excluding terminal activities and the flow of vehicles. Figure 7 depicts the layout of the AICM model developed for the study. 


\section{Estimating peak hour capacity}

Scenarios were constructed in order to get insight into the capacity of AICM. The simulation model was then used to measure the proposed key performance indicators (KPIs) for the airport:

- runway utilisation in peak hour

- $\quad$ runway utilisation during the day

- Terminal 1 utilisation in peak hour

- Terminal 1 utilisation during the day

- Terminal 2 utilisation in peak hour

- Terminal 2 utilisation during the day

- taxiway elements utilisation in peak hour

- taxiway elements utilisation during the day.

\section{Runway analysis}

The analysis of the model confirmed that runway capacity is the most limiting factor of the system. The modelling exercise estimated that the runway utilisation during a typical day is close to $70 \%$. On the other hand, for the peak hour utilisation, the runway is operating at full capacity (98\%). Table 1 illustrates the results obtained after 30 replications of the model. It can be noticed that these figures suggest that there is still potential to use off-peak capacity.

\section{Table 4. Measurements for runway}

\begin{tabular}{|l|l|l|l|}
\hline Parameter & $\begin{array}{c}\text { Average } \\
\text { utilisation }\end{array}$ & $\begin{array}{c}\text { Minimum } \\
\text { utilisation }\end{array}$ & $\begin{array}{c}\text { Maximum } \\
\text { utilisation }\end{array}$ \\
\hline $\begin{array}{l}\text { Runway usage } \\
\text { (Peak hour 3-4 } \\
\text { pm) }\end{array}$ & $98 \%$ & $97.9 \%$ & $98.9 \%$ \\
\hline $\begin{array}{l}\text { Runway usage } \\
\text { (Operative day } \\
\text { 24hrs) }\end{array}$ & $66.41 \%$ & $62.40 \%$ & $70.2 \%$ \\
\hline
\end{tabular}

\section{Terminal gates analysis}

The situation of the terminal gates results are of particular interest for the study. The reason for this is that there are hard restrictions regarding the allocation of airlines in both terminals due to the airline-airport relationship that allocates T2 for the use of Aeromexico while $\mathrm{T} 1$ is used for a mixture of airlines both domestic and international. This allocation might in turn affect the efficient management of the terminals. Table 5 illustrates the utilisation of the gates in both terminals during the day and during the peak hour. 
Table 5. Measurements of gate buildings usage for the 30 simulations

\begin{tabular}{|c|c|c|c|}
\hline Parameter & Average use & Minimum use & Maximum use \\
\hline Terminal 1 Gate usage (3-4 pm) & $74 \%$ & $68 \%$ & $88 \%$ \\
\hline Terminal 1 Gate usage (24hrs) & $51 \%$ & $50 \%$ & $100 \%$ \\
\hline Terminal 2 Gate usage (3-4 pm) & $72.9 \%$ & $64.1 \%$ & $85 \%$ \\
\hline Terminal 2 Gate usage (24hrs) & $44 \%$ & $43.08 \%$ & $100 \%$ \\
\hline
\end{tabular}

In Table 5, the terms average, minimum and max refer to the values obtained during the simulation runs, in other words after running several times the scenarios, due to the uncertainty of the operation, we will have average values and in some moments a minimum use and maximum one. It is noteworthy that the $100 \%$ is not achieved during the peak hour. This situation makes more evident that due to the runway as the limiting element of the system, during the peak hour, the utilisation of both terminals does not reach their operational potential. As it can also be noted, the utilisation of Terminal 2 is lower than Terminal 1; this might be the consequence of Aeromexico operating mainly in Terminal 2.

Simulation modelling also reveals that the gates at the terminal buildings are able to handle more traffic; however focus should be put into the time slots where the entrant carriers would like to operate. The negotiation between carriers and airport authorities is key if the airport wants to keep a good level of service for the carriers and passengers. An example of this situation could be the allocations of flights in the morning slots as now some LCC carriers from the USA are doing (e.g. Southwest and Jet Blue).

\section{Taxiway network analysis}

For the analysis of the simulation model, we could identify two taxiway (TWY) segments that present some problems. On the north from the runways, the TWY B (see Figure7) which is parallel to the northern runway presents congestion problems during the day. In addition, TWY A, which connects Terminal 2 with the northern runway, also shows congestion problems.

\section{Table 6. Measurements of taxiway usage}

\begin{tabular}{|l|l|l|l|}
\hline & Maximum Average & Minimum & Maximum \\
\hline TWY B queue (3-4 pm) & 4 & 3 & 6 \\
\hline TWY B queue lengths & 5.5 & 4 & 8 \\
\hline TWY A (3-4 pm) & 7 & 5 & 11 \\
\hline TWY A queue lengths & 3.8 & 2 & 5 \\
\hline
\end{tabular}

We identified potential causes of this situation:

- The heavy aircraft type coming from Terminal 1 that need to use the southern runway for takeoff (since it is the longest runway), need to cross the northern one with the consequence of blocking the runway for longer than the expected runway occupancy time, which should be the optimal situation for operational purposes.

- Since all the gates of T1 use TWY B for positioning themselves at the head of the northern runway any incident within this taxiway might cause problems and delays in the TWYB. Furthermore, due to this configuration, the TWY works like a funnel where all the aircraft coming from $\mathrm{T} 1$ need to line up in order to take their position at any runway. 
In the case of TWY A, the one that connects T2 with the northern runway, we identified a similar situation as in T1; however the aircraft coming from Terminal 2 can use TWY "A-1" for taking position at the southern runway.

\section{The impact of bigger aircraft}

Some carriers have declared their intentions of operating flights to Mexico City Airport using the biggest aircraft models: Airbus A380 or Boeing 747-8. For this reason, it is important to get insight about the impact that this new aircraft technology would have in the system. Therefore we used the model of the airport for analysing the impact of AirFrance's A380 which operates three times per week to/from Paris.

The results showed that the elements of the system were able to absorb the traffic without significant change in comparison with the scenario without the A380. The only element that was sensitive to the introduction of the A380 was the runway utilisation, whose utilisation rate was shifted as Figure 9 illustrates.

Figure 9. Effect of the introduction of the A380 in the RWY utilisation

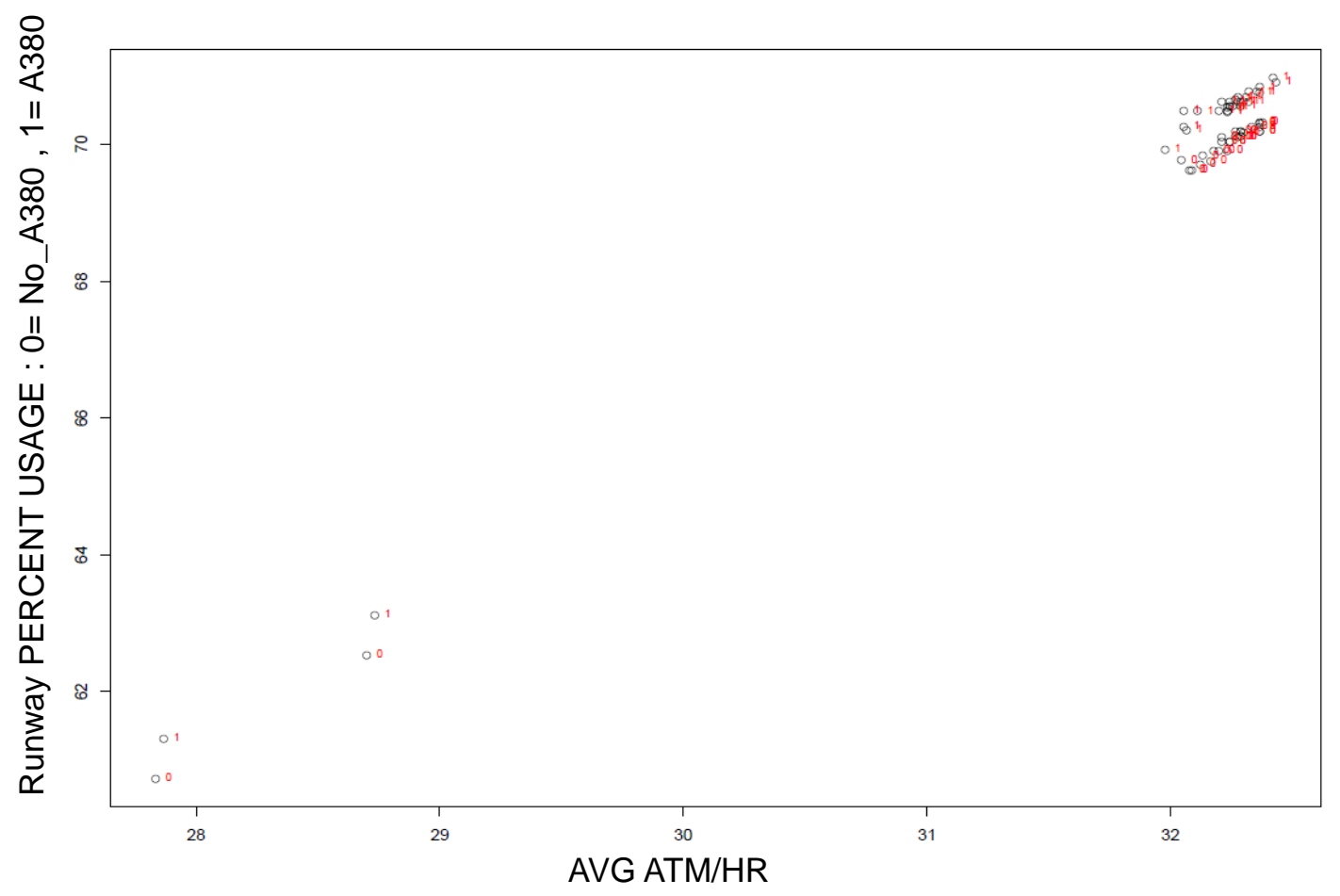

In Figure 9, one can see the dots with a "0" and a "1" label. The " 0 " represents the values of the runway utilisation in the scenario without the A380, while the "1" represents the scenario with the A380 present in the traffic. The figure shows how the scenario of the A380 produces an average utilisation of the runway higher than the one without it. It is shifted up as a result of the introduction of the A380 in the operation of the day. The remaining parameters like Terminal 1, Terminal 2 gate utilisation, or the levels of congestions were not affected. We performed statistical tests and the only parameter that was significantly affected was the runway utilisation. This analysis suggests that while in average the runway utilisation during the day is affected, if the operation of big aircraft is located in a less busy time the facilities would absorb the operation without a problem. 


\section{Conclusions on the situation of Mexico City analysis}

The airport of Mexico City is a facility which will continue operating until the new airport is ready. Until that day comes, tools and actions are required for increasing the current capacity as much as possible. We presented simulation-based analysis as one tool for supporting the sweating-the-assets decision making.

Different factors play an important role for the limitation of capacity in this airport. Unlike Schiphol, technical restrictions are the main blocker for growth and we presented one tool that can be used for releasing this airport's remaining potential of growth.

By using simulation-based analysis we identified runways as the main constraint for increasing the capacity; however under clever allocation of traffic we are still able to use the airport for absorbing new entrants as the analysis of the model suggests. These tools can also be used for analysing the impact of actions like different procedures for taxi in/out together with flexible gate usage or the approaches for Air Traffic Control (ATC) such as the ones proposed in SESAR and NextGen.

\section{Comparison of Schiphol and International Airport of Mexico City}

Both airports play an important role in connecting the region to the world and both airports have problems to meet the growing demand for connectivity in their regions. Here the comparison stops. Schiphol Airport growth potential is limited by environmental limitations in terms of noise and emissions while the International Airport of Mexico City is limited by the technical capacity of the runway and air traffic control. Both cases demonstrate that defining the maximum capacity of an airport cannot be done by just assessing one variable (i.e. runway capacity) but that for each airport a different mix of variables needs to be studied.

The various causes for both airports will result in different sets of analysis and parameters to optimise the existing capacity at the airport. In the case of Schiphol Airport, the pressure today is on the allocation of slots amongst the airlines who want to operate at the airport and to incentivise non-hub airlines to move to reliever airports in the system. Optimising capacity at the airport requires the use of the most modern fleet and collaboration with the stakeholders in the vicinity of the airport for improving the system of hinder control.

In the case of the International Airport of Mexico City, the technical capacity of the available infrastructure must be analysed for a better understanding of the potential of the airport and the impact of new aircraft or traffic in the system. For this challenge, simulation tools can be used effectively for analysing the performance and risk related to new decisions and configurations of facilities and traffic within the system. The optimisation of airport capacity in this case has to be done by improving the operational procedures at the airport, by introducing flexibility in the use of facilities and by innovating ATC-procedures and/or technology.

To summarise, the cases of Schiphol Airport and the International Airport of Mexico City demonstrates that airport capacity is a function of many dependent and independent variables. These include hard limitations like infrastructure, technology such as aircraft or ATC-equipment, and soft limitations like business models, operating procedures, flight schedules and regulations like maximum 
allowed noise hinder. Consequently the limitations of airport capacity by definition will differ for each existing airport, so will the set of measures that are required for optimising the existing capacity.

\section{References}

ACI (2015), ACI Annual World Airport Traffic Report: Aircraft Movements, Airports Council International, www.aci.aero

AICM (2015), History of the Airport, Mexico City International Airport. www.aicm.com.mx

Airbus (2015), Global Market Forecast 2015-2034. Flying on Demand Deutsche Bank Toulouse, 22 January 2015.

Aeromexico (2015), Aeormexico, www.aeromexico.com

Barnhart, C., D. Fearing, A. Odoni and V. Vaze (2012), "Demand and capacity management in air transportation". EURO Journal on Transportation and Logistics, Vol. 1/1, pp. 135-155. DOI:10.1007/s13676-012-0006-9

Boeing (2015), Current market outlook 2015-2034. Boeing Commercial Airplanes. www.boeing.com

Boosten, G., (2008), "The importance of Schiphol Mainport for the northern part of the Randstad region: The Schiphol Paradox". In de Jong D., B. Kaashoek and W.-J. Zondag (eds.), Bleu Skies or Storm Clouds: Science Guide.

Bundesverband der Deutschen Luftverkehrswirtschaft (2015) Aircraft noise report 2015, https://www.bdl.aero/download/2013/aircraftnoisereport2015.pdf

Cohen R., (2017a), "Nu de schaarste toeneemt, krijgen we meer vragen over onze keuzes". Financieel Dagblad, 13 February 2017, https://fd.nl/ondernemen/1187780/nu-de-schaarste-op-schipholtoeneemt-krijgen-we-meer-vragen-over-onze-keuzes

Cohen, R., (2017b), “Opstellen verkeersverdelingsregel luchtvaart stelt ministerie voor hoofdbrekens". Financieel Dagblad, 15 February 2017, https://fd.nl/ondernemen/1187335/opstellenverkeersverdelingsregels-luchtvaart-stelt-ministerie-voor-hoofdbrekens

D'Alfonso, T. and A. Nastasi (2014), "Airport-Airline Interaction: Some food for thought". Transport Reviews, Vol. 34/6, pp. 730-748. DOI:10.1080/01441647.2014.971470

DeNeufville, R. and A. Odoni (2013), Airport Systems: Planning, Design and Management. McGrawHill Education LLC.

Deventer, F. (2010), Geluidbeleid Schiphol, verleden, heden en toekomst. Een geschiedenis in vogelvlucht. Paper presented at the NSG De toekomst van geluidshinderbestrijding, Utrecht, https://nsg.nl/file/91/NSG_verslag_hr_100420.pdf

DOF (2014), "Declaratory: Saturation at the Mexico City International Airport". Official Newspaper of the Federation (DOF), Mexico.

Eindhoven Airport (2015), Major improvement to external area and accessibility [Press release]. https://d21buns5ku92am.cloudfront.net/33708/pdf/campaigns/123476-20160302142936-majorimprovements-to-external-area-and-a.pdf 
Eurocotrol (2015), Wake Vortex, www.eurocontrol.int/articles/wake-vortex

FAA (2015), FACT3: Airport Capacity Needs in the National Airspace System. https://www.faa.gov/airports/planning capacity/media/FACT3-Airport-Capacity-Needs-in-theNAS.pdf

Ferjan, K. (2014), Airline Cost Management Group (ACMG). Airline Cost Conference, Geneva.

FlightRadar24 (2017), http://flightradar24.com

Galland, D. and C. Lassen (2011), Aeromobility and Social Consequences: The Case of Mexico City International Airport. http://planninglatinamerica.wordpress.com

Graham, B. and C. Guyer (1999), "Environmental sustainability, airport capacity and European air transport liberalization: irreconcilable goals?" Journal of Transport Geography, Vol. 7/3, pp. 165180. DOI: 10.1016/S0966-6923(99)00005-8

Group Schiphol (2016). Schiphol Annual Report 2015.

Herrera, A. (2012), "Simulation Model of Aeronautical Operations at Congested Airports: The case of the Mexico City International Airport", Mexican Institute of Transport, No. 365, Queretaro, Mexico.

I\&M and MIN (2016), Schiphol Action Programme. The Hague. www.government.nl/...schiphol/IenM+actieagenda+Schiphol

Inalhan, G. and C. Pasaoglu (2014), Macro Modelling of the European Air Traffic Network: A data analytic perspective. Paper presented at the Resilience ATC Madrid.

International Air Transport Association (IATA) (2014), Annual Review 2014. Technical report $69^{\text {th }}$ Annual General Meeting Cape Town.

ITF (2016), Airport Demand Forecasting for Long-Term Planning, ITF Round Tables, OECD Publishing, Paris. DOI: http://dx.doi.org/10.1787/9789282108024-en

Jacquillat, A. and A. Odoni (2015), "Endogenous control of service rates in stochastic and dynamic queuing models of airport congestion". Transportation Research Part E: Logistics and Transportation Review, Vol. 73, pp. 133-151. DOI:10.1016/j.tre.2014.10.014

Janic, M. (2008), "The Future Development of Airports: A Multidimensional Examination". Transportation Planning and Technology, Vol. 31/1, pp. 113-134. DOI: $10.1080 / 03081060701835803$

Janic, M. (2016), "Analyzing, modeling, and assessing the performances of land use by airports". International Journal of Sustainable Transportation, Vol. 10/8, pp. 683-702. DOI:10.1080/15568318.2015.1104566

Jarag, D. (2005), Airport Marketing. Strategies to Cope with the New Millenium Environment. Ashgate Publishing Limited, Hampshire.

KiM (2017), The Potential of the long-haul low-cost business model and its impact on the Netherlands. Netherlands Institute for Transport Policy Analysis, Ministry of Infrastructure and the Environment. https://www.kimnet.nl/actueel/nieuws/2017/02/09/the-potential-of-the-long-haullow-cost-business-model-and-its-impact-on-the-netherlands

Mendoza, E., C.A. Zuñiga and J.L. Martínez (2014), "Aeropuerto Internacional De La Ciudad De México "Benito Juárez": Revisión Histórica De Un Problema Recurrente De Saturación". Revista de Investigación e Innovación en Ingeniería, Vol. 2/3, pp. 6-17, Narváez Rincón / Universidad Simón Bolívar, ISSN: 2344-8652. 
Moes, W., R. Veld and G. Teisman (2009), Duurzame ontwikkeling en Schiphol: naar een creatieve confrontatie. Een onderzoek naar de duurzame ontwikkeling van het governance -veld rond Schiphol. (RNMO reeks adviezen nr A14 [2009]). RMNO, The Hague.

Mujica Mota, M., G. Bosten, N. De Bock, E. Jimenez, P. de Sousa, (2017), "Simulation-based turnaround evaluation for Lelystad Airport". Journal of Air Transport Management, Vol. 64/A, pp. 21-32.

Mujica Mota, M. and G. Boosten (2014), "Extended definition of capacity in Airport Systems". In Proc. of NGI Next Generation Infrastructures, Vienna.

Netherlands, Stichting Airport Coordination, (2016), Capacity declaration Amsterdam Airport Schiphol; summer 2016. http://merrick.marketing-desktop.nl/files/editor/assets/Airport Coordination Netherlands/docs/DECCAP AMS S2016.pdf

OAG Producer (2016), On-time performance results for airlines and airports. https://cdn2.hubspot.net/hubfs/490937/Free_Reports/Punctuality_League_2015/PunctualityLeague Report2015.pdf

OAG (2015), OAG Database for MMMX, www.oag.com

Reichmuth, J., P. Berster and M.C. Gelhausen (2011), "Airport Capacity Constraints: Future avenues for growth of global traffic". CEAS Aeronautical Journal, Vol. 2/1-4, pp. 21-34. DOI:10.1007/s13272-011-0034-4

SESAR JU (2017), Workpackages Summary, http://www.sesarju.eu/discover-sesar/workpackagessummary

Upham, P., D. Raper, C. Thomas, M. McLellan, M. Lever and A. Lieuwen (2004), "Environmental capacity and European air transport: stakeholder opinion and implications for modelling". Journal of Air Transport Management, Vol. 10/3, pp. 199-205. DOI:10.1016/j.jairtraman.2003.10.016

Upham, P., C. Thomas, D. Gillingwater and D. Raper (2003), "Environmental Capacity and Airport Operations: Current issues and future prospects". Journal of Air Transport Management, Vol. 9/3, pp. 145-151. DOI:10.1016/s0969-6997(02)00078-9

Veer, Floris van der and T. Bertnsen (2016), Air Service Development at AMS, CPH and FRA. Bach. Thesis, Amsterdam University of Applied Sciences. 


\section{Notes}

${ }^{1}$ In aviation level of service is defined by IATA/ACI as: "The concept of Level of Service (LoS) is an aggregated guidance framework for the planning of new terminal facilities as well as for monitoring the operational service performance of existing facilities". https://www.iata.org/services/consulting/Documents/Level-of-Service-Assessment-Handout.pdf (assessed 18 February 2017).

${ }^{2}$ Connectivity (the aggregate of unique destinations and frequency) can be seen as an indicator how well a region is connected to other regions in the world.

${ }^{3}$ The peak hour capacity is an indicator of the maximum number of aircraft and thus passengers, baggage and cargo that can be handled in one hour of operations. The take-offs and landings related to this number of aircraft are the maximum of ATM. If the runways are the limiting factor the ATM's define the peak hour capacity.

4 Source Schiphol Group: https://www.schiphol.nl/en/schiphol-group/page/credit-rating/ (accessed 07 January 2017).

${ }^{5}$ A work load unit (WLU) is a standard for a passenger or an amount of cargo.

${ }^{6}$ Wake vortex turbulence is defined as turbulence which is generated by the passage of an aircraft in flight. It will be generated from the point when the nose landing gear of an aircraft leaves the ground on takeoff and will cease to be generated when the nose landing gear touches the ground during landing (Eurocontrol, 2015). 
